\title{
The Association between Individual Audit Partners' Risk Preferences and the Composition of their Client Portfolios
}

\author{
Eli Amir \\ Tel Aviv University, Recanati Graduate School of Management \\ Tel Aviv 69978, Israel \\ eliamir@post.tau.ac.il \\ Juha-Pekka Kallunki* \\ University of Oulu, Department of Accounting and Finance \\ P.O. Box 4600, FIN-90014 University of Oulu, Finland \\ Juha-Pekka.Kallunki@oulu.fi \\ Henrik Nilsson \\ Stockholm School of Economics, Department of Accounting \\ P.O. Box 6501, SE-113 83 Stockholm, Sweden \\ Henrik.Nilsson@hhs.se
}

Fortcoming in Review of Accounting Studies

* Corresponding author. The authors thank seminar participants at the University of Auckland (New Zealand), Bocconi (Italy), Columbia University, Copenhagen Business School (Denmark), University of Cyprus (Cyprus), IE Business School (Spain), University of Jyväskylä (Finland), the University of New South Wales (Australia), the Norwegian Business School, BI (Norway), the University of Oulu (Finland), Stockholm School of Economics (Sweden), and Victoria University (Wellington, New Zealand) for many useful comments. The authors also thank Euroclear Sweden, Finansinspektionen and The Swedish National Council for Crime Prevention (Brå) for providing the requisite data. This research was conducted while Eli Amir was a faculty member at London Business School. Eli Amir is grateful to the London Business School for research support. This study has been evaluated and approved by The Regional Ethical Review Board in Umeå, Sweden (DNR 08:074 Ö and DNR I3-0449/2009). All remaining errors are our own. 


\title{
The Association between Individual Audit Partners' Risk Preferences and the Composition of their Client Portfolios
}

\begin{abstract}
We explore whether audit partners' attitude towards risk, as measured by their personal criminal convictions, are reflected in the composition of their client portfolios. Analyzing a unique dataset of Swedish audit partners' criminal convictions, we find that the clients of audit partners with criminal convictions are characterized by greater financial, governance and reporting risk than those of audit partners without criminal convictions. Also, clients of audit partners with criminal convictions pay larger audit fees, on average, than those of auditors without criminal convictions.
\end{abstract}

JEL Classification: M41, M42, G30, K42

Keywords: Audit Partners, Criminal Convictions, Client Portfolios, Audit Risk, Accounting Conservatism 


\section{The Association between Individual Audit Partners' Risk Preferences and the Composition of their Client Portfolios}

\section{Introduction}

Research shows that auditors' portfolio management decisions are affected by the client's perceived risk, and that auditors assess client risk on the basis of client-specific characteristics, such as financial condition, the level of corporate governance and the quality of financial reporting. With few exceptions, this line of research typically assumes that auditors are homogenous in their attitudes towards client risk. To date, little is known about how individual audit partners' personal risk preferences affect client portfolio decisions, although it is the partners who make these decisions within the audit firm. The lack of empirical archival research in this area is due to data limitations, because in many countries, including the United States and the United Kingdom, individual auditors are not required to sign their names on the audit reports. However, such a requirement is currently in practice in some countries, permitting individual partner-level analysis in these countries. ${ }^{1}$

This study uses a proprietary data set from Sweden to explore whether audit partners' personal risk preferences, as measured by their prior criminal convictions, are reflected in their client portfolio risk. ${ }^{2}$ In particular, we predict that audit partners with criminal convictions have riskier clients who pay higher audit fees. We base our predictions on studies that have established the association between crime and risk-taking behavior and on recent studies that

\footnotetext{
${ }^{1}$ See, for instance, Chin and Chi (2008) and Chen et al. (2010). The Public Company Accounting Oversight Board (PCAOB) has issued a concept release soliciting comments on whether it should require engagement partners to sign audit reports to increase transparency and enhance partners' accountability (PCAOB 2009).

${ }^{2}$ The criminal convictions discussed here are not related to the auditors' work. Our analysis does not imply that criminally convicted auditors necessarily exhibit illegal or even faulty professional judgment in their audit work. Instead, we argue that criminal convictions indicate a greater propensity for risktaking, in general and in particular the audit work.
} 
have considered either explicitly or implicitly auditors' propensity to take risks. Based on the current literature, we argue that criminal convictions can be used as a proxy for audit partners' propensity to take audit risks regardless of the severity of the crime. Hence, we examine the effect of this personal attribute on a specific aspect of the audit work - the level of the client risk - where auditors' risk-taking, resulting either from profit maximization or personal traits, such as overconfidence, plays an important role.

Our database includes all personal criminal convictions of audit partners of listed Swedish firms. There are a total of 482 Swedish audit partners in our sample, of whom 53 have been convicted of a crime according to official court records, while seven additional audit partners have been suspected of serious crimes by the police authorities according to a register maintained by the Swedish National Police Board. These convictions are mostly related to reckless and drunk driving but also include more serious crimes. While it may seem that reckless and drunk driving are not a factor in auditing, the literature, as reviewed below, shows that the propensity to take risks by individuals who have been convicted of these crimes is greater and that these individuals are overconfident.

We contribute to the emerging literature on the role of individual auditors' characteristics in audit engagements by exploring how audit partners' personal risk preferences affect their decisions regarding the level of the clients' risk. As Francis (2011) points out, very little is known about the people who conduct audits, although we know from the psychology literature that various characteristics affect an individual's behavior and decisions. The audit process and the decisions made during this process are affected by these personal characteristics, an issue explored here. 
Our empirical results support the prediction that audit partners with criminal convictions engage in riskier audits than those without criminal convictions. In particular, we find that clients of audit partners with criminal convictions have a greater financial risk, as reflected in their financial ratios, and a greater governance risk, as reflected in their board composition, than clients of audit partners without criminal convictions. Moreover, clients of audit partners with criminal convictions have a greater financial reporting risk; these firms report less conservatively, and are characterized by larger discretionary accruals and smaller goodwill writeoffs. We also find support for the prediction that firms audited by auditors with criminal convictions pay, on average, higher audit fees than firms audited by auditors without criminal convictions. However, we find some evidence supporting the argument that auditors with criminal convictions charge their clients a smaller fee per unit of risk than those without criminal convictions.

We proceed as follows: In Section 2, we review the literature and develop our testable predictions. Section 3 discusses the sample and data, and Section 4 presents our empirical analysis and results. Section 5 discusses our conclusions and policy implications.

\section{Literature Review and Testable Predictions}

\subsection{Criminal Convictions as an Indicator of Risk-Taking Behavior}

Becker (1968) and Ehrlich (1973) argue that individuals engage in criminal acts if the expected gain from that act is greater than the expected costs; these individuals are willing to take the risk of being caught and convicted in court because the expected benefits compensate them for taking such risks. Therefore, a decision to engage in criminal activities can be seen as rational behavior under uncertainty. Ehrlich (1973) highlights an important implication of these 
models: a risk-neutral individual will spend more time on illegal activities than a risk-avoider, and a risk-seeker will spend more time on such activities than both.

Unlike the economic approach to crime, behavioral research links crime to personal attributes, and in particular to overconfidence; individuals who engage in criminal activities tend to be overconfident and overoptimistic risk-takers who underestimate the probability of negative outcomes (see Eide et al., 2006; Garoupa, 2003; Palmer and Hollin, 2004; and Walters, 2009). Furthermore, previous studies have shown that overconfidence is a major determinant of traffic accidents. For instance, Sandroni and Squintani (2004) find that while most drivers possess fairly accurate perception of risk, they believe that these risks do not pertain to them personally. Iversen and Rundmo (2002) argue that individuals characterized by risk-taking behavior are more involved in risky driving and violating driving rules. Junger et al. (2001) analyze police databases and find that willingness to take risks is a common factor underlying criminal and risky behavior in traffic. Finally, McKenna (1993) shows that the illusion of control, related to overconfidence, characterizes risky drivers.

Previous studies have also linked speeding tickets to risk-taking and economic decision making. Grinblatt and Keloharju (2009) measure investors' attitude towards risk in terms of the number of speeding tickets they have received and find a positive relation between the number of speeding tickets and risk-taking in the stock market. ${ }^{3}$ This study suggests that even a relatively minor traffic violation, such as speeding, can capture differences in behavior.

Auditors, like other individuals, possess different personal characteristics, including different preferences regarding risk and tendency to criminal behavior. Several experimental

\footnotetext{
${ }^{3}$ Fisman and Miguel (2007) find that the number of unpaid parking tickets by United Nation diplomats is significantly related to the level of corruption and legal enforcement in their home country. This study shows that even the most common traffic violation may be used as an indication of character.
} 
studies have examined the diversity in auditors' personal characteristics related to their propensity to take risk, and how these characteristics affect the audit work under different circumstances. For example, Schatzberg et al. (2005) find a positive link between auditors' levels of moral reasoning and audit misreporting. They also find that as the economic penalties increase, auditor misreporting and fees decrease and the moral reasoning effect diminishes. Cohen and Trompeter (1998) find that the more aggressive audit partners of large audit firms are the more likely to recommend accepting the client's relatively aggressive accounting choices in order to retain the client in the increasingly competitive markets of audit services. They also find that auditors are more willing to bid for existing than potential clients, a finding consistent with the prospect theory of Kahneman and Tversky (1979) - individuals are risk-averse with respect to gains and risk-seeking with respect to losses. Farmer (1993) examines risk attitudes of individual auditors in large audit firms and finds that tendencies for both risk aversion and risk preference occur among auditors.

Prior studies have also examined behavioral biases, such as overconfidence, among auditors. Messier et al. (2008) find that audit partners exhibit significant overconfidence in the ability of their subordinates to detect errors. Kennedy and Peecher (1997) find that auditors are overconfident regarding both their own and their subordinates' technical knowledge; this overconfidence increases with the knowledge gap between supervisors and subordinates.

While many studies have looked at audit firm level data, recent studies have focused more on office-level analysis. For example, Reynolds and Francis (2000) examine client accruals and auditor going concern reports at the office level of analysis and find evidence suggesting that auditors treated larger clients more conservatively. Krishnan (2005) finds that Houston-based 
clients of Arthur-Andersen recognized bad news in a less timely manner than Houston-based clients of other Big-6 audit firms.

While audit-firm-level and office-level analyses have greatly contributed to our understanding of the causes and consequences of audit risk, quality and pricing, significant insights can be obtained by bringing the analyses down to the level of individual auditors. Auditing requires expertise and skills as well as personal judgment in assessing the overall audit risk, the appropriate scope of the audit and the accounting choices made by client firms. Therefore, auditors' personal attributes have a significant effect on their decisions regarding the audit work.

The literature discussed above suggests that auditors differ from each other in their personal risk preferences. We argue that auditors who have been convicted of crimes have a higher propensity for risk in their personal as well as their professional work. In particular, economic theory of crime implies that auditors with criminal convictions may be more willing to take risks if the expected gain from taking such risk is greater than the expected costs. For instance, they may prefer to engage in auditing more risky companies or to allow these companies to adopt less conservative accounting if they can charge higher audit fees. In addition, behavioral studies imply that auditors' criminal convictions may reflect overconfidence, which leads to more aggressive risk-seeking behavior.

\subsection{Testable Predictions}

Prior experimental studies have shown that auditors evaluate client-related risks to avoid losses from audit engagement. For instance, Johnstone (2000) argues that audit partners evaluate client-related risks, and use those evaluations to determine whether the audit firm will suffer a 
loss on the audit engagement due to potential litigation. Other studies show that auditors assess client-specific risk by using the client's financial condition (Pratt and Stice, 1994), level of corporate governance (Cohen and Hanno, 2000), and quality of financial reporting (Cohen and Trompeter, 1998).

The audit firm level results on whether auditors vary by their tolerance towards client risk are somewhat contradictory. Jones and Raghunandan (1998) argue that large audit firms avoid risk because they have more to lose from audit failure. In contrast, Francis and Krishnan (2002) argue that large audit firms accept high-risk clients because they can diversify that risk across their client portfolio. Therefore, the question of how audit partners' personal risk preferences affect client portfolio decisions is still an open one.

We argue that audit partners with prior criminal convictions are more willing to accept riskier clients than auditors without criminal convictions. Consequently, we expect clients of audit partners with criminal convictions to be characterized by higher financial risk, weaker governance and less conservative financial reporting, than clients of audit partners without criminal convictions.

Simunic and Stein (1990) focus on financial risk and find that auditor's risk increases with the degree of clients' financial risk. Hence, an audit partner with a criminal conviction, who is more willing to engage in riskier audits, is more likely to have clients with greater financial risk. This leads to the following prediction:

Prediction 1: Clients of audit partners with criminal convictions have a greater financial risk than those of audit partners without criminal convictions. 
Weaker corporate governance increases the audit risk because weaker governance is associated with higher likelihood of fraud, misappropriations of funds, and opportunistic accounting decisions, which could also lead to higher litigation risk. An audit partner facing clients with weaker governance is required to take that into account in planning and executing the audit. Cohen and Hanno (2000) report that the governance structure of the client firm affects auditors' decision to accept clients. Due to their greater tolerance of risk, audit partners with criminal convictions are more likely to tolerate weaker governance of their client firms, which leads to our second prediction:

Prediction 2: Clients of audit partners with criminal convictions have weaker governance than clients of audit partners without criminal convictions.

The level of conditional accounting conservatism, often measured as the asymmetric recognition of good and bad economic news in earnings, is regarded as a fundamental characteristic of high quality financial reporting. Also, as Watts (2003) and Skinner (1997) argue, the risk of litigation compels auditors to require conservative accounting because damages are assessed when financial statements overstate net assets and profitability rather than understate them. Qiang (2007) finds that litigation risk is positively related to conservatism. Basu et al. (2001) find that the clients of Big-8 auditors show a greater degree of conservatism than those of Non-Big-8 auditors. We expect audit partners with criminal convictions to be more tolerant of aggressive accounting treatment, resulting in less conservative accounting. This is because audit partners with criminal convictions are willing to take a greater risk when selecting clients, compared to audit partners without criminal convictions. This leads to the third prediction: 
Prediction 3: Clients of audit partners with criminal convictions report less conservatively than those of audit partners without criminal convictions.

The first three predictions deal with different aspects of audit risk - financial, governance and reporting risks. Next, we develop predictions regarding potential difference between audit fees paid by client firms audited by audit partners with and without criminal convictions. Prior studies on audit pricing (Simunic, 1980, among others) have documented a positive relation between audit fees and client-firm risk. Also, Hribar et al. (2010) find that high audit fees predict accounting fraud, restatements, and SEC comment letters, after controlling for other measures of accounting quality; these findings support the view that audit fees summarize the auditor's unobservable private information about client firms' risk. If client firms of audit partners with criminal convictions are indeed more risky than those of audit partners without criminal convictions, as we argued in our previous predictions, then these client firms are expected to pay higher audit fees, on average, compensating the auditors for the additional audit risk. In particular, audit partners face significant personal reputation and audit firm-level litigation risks in cases of audit failures. Being aware of these greater audit risks inherent in their clients, audit partners require compensation for bearing that risk in terms of higher audit fees. Moreover, audit partners may increase the scope of the audit in an attempt to manage the higher perceived risk, increasing audit fees. ${ }^{4}$ This leads to the fourth prediction:

\footnotetext{
${ }^{4}$ We interviewed several audit partners in leading Swedish firms. These partners argue that the large audit firms are less willing to take high-risk clients to avoid loss of reputation. These firms also charge higher fees for audit services offered to these clients to compensate themselves for additional risk and even avoid taking these clients. Consequently, smaller audit firms have more high-risk clients that pay higher audit fees. Audit partners of the large audit firms also pointed out that they have dismissed auditors exhibiting excessive risk-taking, and these auditors are often hired by smaller firms. These interviews should be viewed as anecdotal evidence supporting our predictions.
} 
Prediction 4: Client firms of audit partners with criminal convictions pay higher audit fees, on average, due to additional audit risk.

We expect Prediction 4 to hold because the client firms that are audited by auditors with criminal convictions are more risky. However, it is still possible that in a competitive audit market and holding the audit risk of the client firm constant, an auditor with a criminal conviction will bid a lower price for a client due to increased confidence and lower risk aversion. As a result, risk-seeking auditors will win risky clients because they under-bid riskaverse auditors for the same audit engagement. On the demand side, more risky clients have an incentive to hire a risk-seeking auditor only if doing so reduces the cost of the audit. This argument relies on audit markets being competitive. However, the audit market may not be fully competitive due to licensing, regulation and rules of conduct imposed by the audit profession, which may limit audit partners' ability to under-bid for clients. Also, switching auditors is often regarded as a negative signal, which may limit the auditor's ability to under-bid for new clients. This leads to our fifth and final prediction:

Prediction 5: Audit partners with criminal convictions will charge a lower audit fee per unit of risk.

\section{Institutional Background, Sample and Data Sources}

\subsection{Audit Profession in Sweden}

Two types of auditors in Sweden are allowed to audit listed firms: approved auditors and authorized auditors. To become an approved auditor, the candidate must obtain a bachelor's 
degree, practice for at least three years, and pass an examination in professional competence. To become an authorized auditor, the approved auditor must obtain a master's degree, complete five years of practice, and pass an examination for authorized auditors. The audit certification is valid for five years; after which the auditor must reapply to the supervisory board for license renewal. All limited liability companies in Sweden must be audited on an annual basis. Normally, the audit partner in charge of the audit engagement is responsible for key clientspecific decisions, including the scope and pricing of the audit engagement. Therefore, audit partners' personal attributes, as measured by their criminal convictions, are likely to play an important role in audit-related decisions.

The audit market in Sweden is largely controlled by PWC, Ernst \& Young, KPMG and Deloitte; these firms employ $56 \%$ of the authorized auditors, and $29 \%$ of the approved auditors in Sweden. ${ }^{5}$ Their market share is about $40 \%$, and it is increasing with client size. ${ }^{6}$ Auditors and registered public accounting firms are subject to independent quality control every six years, and an auditor who audits at least one public company should be evaluated every three years. Also, mandatory partner rotation was not practiced in Sweden during the sample period.

Normally, convicted individuals in western countries, including Sweden, cannot complete the training and obtain the license allowing them to become certified public accountants. However, in many western countries, including Sweden, individuals are barred from becoming certified auditors only if they have been convicted of violent or economic-related crimes. Also, it is possible that auditors are convicted of crimes after receiving their license and these crime convictions rarely trigger the withdrawal of a license. In particular, the Supervisory Board for

\footnotetext{
${ }^{5}$ Our sample period still includes Arthur Andersen, and hence, we have five big firms in our sample.

${ }^{6}$ According to the Swedish Ministry of Justice, there were 2,321 approved auditors and 1,787 authorized auditors in 2008 (www.sweden.gov.se/sb/d/584).
} 
Public Accountants (SBPA) in Sweden examines the criminal records of applicants every five years when certification is renewed. The Supervisory Board also checks whether auditors have had any disputes with the tax authorities, that they are not bankrupt and that they do not have legal guardianship. However, criminal record checks are limited to economic-related crimes and crimes related to the audit profession.

Auditing standards issued in Sweden are based on International Auditing Standards, but some additions and changes have been made to certain standards to make them consistent with Swedish law. To maintain auditor independence, Swedish and European laws require that auditors have neither a financial interest nor any close personal relationship with the client. Audit failures may result in litigation by clients and disciplinary sanctions by the profession. However, litigation risk in Sweden is lower relative to the United States (see Choi et al., 2008). The SBPA issues disciplinary sanctions against auditors in certain cases, although these cases are not common. ${ }^{7}$

\subsection{Sample and Data Sources}

The sample of firms includes all listed companies in Sweden monitored by the Swedish securities regulator (Finansinspektionen) during 1999-2007. The identities of auditors in our sample firms were also obtained from Finansinspektionen. Data on auditors' criminal convictions are taken from Brå (The Swedish National Council for Crime Prevention); this dataset contains information on individuals who have been found guilty by a court of law or

\footnotetext{
${ }^{7}$ According to the 2010-2011 Global Competitiveness Report of the World Economic Forum, the quality of Sweden's auditing and reporting standards is ranked $2^{\text {nd }}$ in the world (ahead of the United States). See: http://www.weforum.org/issues/global-competitiveness.
} 
received summary punishments by prosecutors since $1974 .^{8}$ For each auditor registered, this dataset includes details of the crime and the punishment (the length of unconditional prison sentences, suspended sentences and monetary fines) and the details of the crime (for each crime an exact reference to the law or laws violated is given). The dataset does not, however, contain information on speeding, parking and violations of local bylaws for which the punishment is an on-the-spot fine.

While criminal convictions are proof of prior criminal activity, focusing only on actual convictions could potentially cause a selection bias. This is because the burden of proof is heavier in more serious crimes, as indicated by Korsell (2001). Consequently, serious crimes are likely to be underrepresented in the dataset of actual criminal convictions. This selection bias could be reduced by including data on individuals having been under investigation for serious crimes. Our dataset on suspected criminal actions contains information on all Swedish citizens who have been under investigation for serious crimes since 1991. Suspicion of a crime in this study means that a police investigation had been launched but the prosecutor eventually decided not to pursue the case in court. The database is maintained by the National Police Board and is mainly used by the police, the tax authorities, the customs and the coastguards to coordinate preliminary investigations of individuals in order to prevent, discover and investigate crimes. ${ }^{9}$ We therefore measure criminal behavior in terms of criminal convictions and having been under investigation for suspected criminal actions. Finally, accounting and market data for Swedish listed firms were obtained from Thomson's Datastream.

\footnotetext{
${ }^{8}$ Brå (www.bra.se) aims to reduce crime in Sweden by providing and disseminating data on crime and crime prevention. Brå also produces Sweden's official crime statistics, evaluates reforms, conducts research and provides support to local crime prevention agencies. If the suspect confesses to the crime and it is clear what the punishment will be, the prosecutor may pronounce an order of summary punishment.

${ }^{9}$ These suspected crimes were for: perjury, two cases of book-keeping fraud, tax fraud, two cases of illegal insider trading, and battery.
} 
Table 1 presents a list of the criminal convictions by laws violated and by audit firm size (Big-5 versus Non-Big-5), and the number of suspected crimes. The table shows that the sample is not dominated by small audit firms. While the proportion of criminal activity is higher among Non-Big-5 firms (19.6\%) than in Big-5 firms (11.6\%), the most serious crimes in the sample were committed by Big-5 auditors. ${ }^{10}$

(Table 1 about here)

\subsection{Measures of Audit Partners' Criminal Behavior}

We construct three variables that capture the criminal intensity of the auditors of a given client firm: (i) CONV_AUD1 is an indicator variable that obtains a value of "1" if at least one of the audit partners who audited firm $i$ in year $t$ has been convicted/suspected of a crime, and otherwise "0"; (ii) CONV_AUD2 is the number of convicted audit partners who audited firm $i$ in year $t$. In our sample, the maximum number of convicted audit partners per firm-year is three so $C O N V \_A U D 2 \in[0,3]$; and (iii) $C O N V \_A U D 3$ is the number of convicted audit partners divided by the total number of audit partners for firm $i$ in year $t$.

Table 2 provides comparative information on the criminal activity of auditors, directors, CEOs and main owners (shareholders who hold at least $10 \%$ of the firm's equity). Compared to directors, CEOs and main owners, auditors are less likely to have been convicted or suspected of a crime. This is likely a result of regulating the audit profession. Also, main owners exhibit a greater likelihood of being convicted or suspected of a crime because, unlike directors, executives and auditors, there are no regulatory restrictions on being a major shareholder.

\footnotetext{
${ }^{10}$ The term "auditors with criminal convictions" refers to the 60 auditors that have been either convicted in court (53 auditors) or suspected of serious crimes and hence are included in our sample ( 7 auditors).
} 
(Table 2 about here)

Next, we report descriptive statistics on auditors with criminal convictions. In particular, we expect the following variables to be associated with the probability of being a convicted/suspected audit partner:

(i) GENDER - An indicator variable that is equal to " 1 " if the audit partner is a male and " 0 " if a female. Chin and Chi (2008) show that females are less risk prone and act more ethically than males. Furthermore, Daly (1989), Zahra et al. (2005) and Blickle et al. (2006), among others, have shown that males are more involved in crime than females.

(ii) $A G E$ - The age of the audit partner in the middle of the sample period. Because our dataset covers criminal convictions since 1974, older audit partners are more likely to have such convictions purely due to their age. Hence, we expect convicted/suspected auditors to be, on average, older.

(iii) CLIENTS - the number of client-years audited by the audit partner during the sample period. If audit partners with criminal convictions are indeed taking higher risks in their audit work, they will spend relatively less time on each audit engagement, allowing them to audit more clients and earn more audit fees. Also, if audit partners with criminal convictions audit riskier firms, which are likely to be smaller, the number of clients will, on average, be larger.

(iv) $B I G \_A U D$ - An indicator variable equal to " 1 " if the audit partner is employed by a Big-5 audit firm and " 0 " if not. To maintain their reputation, Big-5 firms are less likely to appoint auditors characterized by a tendency for risk-seeking, and they are likely to impose stricter screening mechanisms and avoid employing individuals with criminal convictions. 
Table 3, Panel A, presents descriptive statistics for the four variables above. Panel B presents means and medians for these variables by different categories of auditors: 53 convicted auditors, 7 suspected auditors (60 convicted/suspected auditors) and 422 auditors without criminal convictions. For the variable $B I G \_A U D$, we compute average of the annual observations for each auditor over the sample period (1999-2007).

While $95 \%$ of audit partners with criminal convictions are males, only $81 \%$ of audit partners without criminal convictions are males (the difference in proportions is significant at the 0.01 level). Also, audit partners with criminal convictions are older, as expected, than those without criminal convictions (significant at the 0.05 level). In addition, they are involved in more audits (significant at the 0.05 level), which is consistent with the arguments that they spend relatively less time on each audit engagement, and that their clients are smaller and hence riskier. Finally, the proportion of audit partners with criminal convictions employed by Big-5 firms $(78 \%)$ is smaller than that of audit partners without criminal convictions employed by Big5 firms $(87 \%)$; this difference is significant only at the 0.10 level. ${ }^{11}$

(Table 3 about here)

\section{Empirical results}

\subsection{Audit Partners' Criminal Convictions and Client Firm Characteristics}

We first examine the risk characteristics of the clients of audit partners with and without criminal convictions. According to Prediction 1, we expect client firms of audit partners with

\footnotetext{
${ }^{11}$ We have also estimated a multivariate logistic regression with an indicator dependent variable equal to one if the audit partner has a criminal conviction, and otherwise zero; the independent variables included the four personal characteristics from panel B of Table 3. The results (not tabulated) show that the effects of audit firm size and gender subsume the effect of the number of clients in a multivariate setting.
} 
criminal convictions to have a greater degree of financial risk. We measure financial risk using three variables (firm and year subscripts are understood):

(i) CURRENT - Current ratio, measured as current assets divided by current liabilities;

(ii) LEVERAGE - measured as total interest-bearing debt divided by total assets; and

(iii) COVERAGE - Interest coverage ratio, measured as $\operatorname{Ln}\{[(\mathrm{EBIT}+\min (\mathrm{EBIT})] /$ Interest $\}$, where EBIT is earnings before interest and taxes, and $\min (\mathrm{EBIT})$ is the minimum value of EBIT in the sample. ${ }^{12}$

We expect CURRENT and COVERAGE (LEVERAGE) to be negatively (positively) associated with the probability of being audited by an auditor with a criminal conviction. We also construct two additional measures of over-all risk:

(iv) SIZE, measured as the natural logarithm of total assets;

(v) $P B$ - market-to-book ratio, measured as market value divided by book value of equity;

We expect SIZE $(P B)$ to be negatively (positively) associated with the likelihood of being audited by an audit partner with a criminal conviction.

According to Prediction 2, companies with weaker governance are more likely to be audited by auditors with criminal convictions. We measure the client firm's quality of the corporate governance using the following three variables:

(vi) $C O N V \_D I R$ - the proportion of board members who have been convicted of a crime;

(vii) CONV_OWNER - an indicator variable that obtains a value of " 1 " if the firm has at least one owner who owns $10 \%$ or more of the firm's equity and who has been convicted of a crime, and otherwise "0"; and

\footnotetext{
${ }^{12}$ We also measured COVERAGE as EBIT/Interest without the logarithmic transformation. Our main results are similar for both measures. However, the denominator (Interest expenses) can have values close to zero. The log transformation makes the variable more stable facilitating statistical testing.
} 
(viii) OUT_DIR - the proportion of outside directors with three or more board memberships in listed Swedish firms (board professionals). Numerous prior studies suggest that the greater proportion of outside directors improves the level of the corporate governance of the firm. Since the Swedish Corporate Governance Code requires almost all directors to be outsiders, we focus on a subset of outside directors, i.e. board professionals.

We expect $C O N V \_D I R$ and $C O N V \_O W N E R$ to be positively associated with appointing an audit partner with a criminal conviction. If the client firm has board members or influential shareholders who have been convicted of crimes, the corporate governance system is likely to be weaker, resulting in greater demand for auditors with criminal convictions. We also expect OUT_DIR to be negatively associated with appointing an audit partner with criminal convictions, because greater board independence improves the level of corporate governance thereby restricting the appointments of risk-seeking audit partners.

Based on Prediction 3, we expect client firms of audit partners with criminal convictions to report less conservatively. We test this prediction by using an asymmetric loss recognition model similar to that of Basu (1997). In addition, we use the following two variables to measure earnings quality:

(ix) DISACC - Discretionary accruals measured using the Jones (1991) model residuals.

(x) WOFFS - The proportion of goodwill that is written off, measured as goodwill writeoffs divided by the amount of goodwill before the writeoff.

Larger discretionary accruals are often used as an indicator of lower earnings quality (Dechow et al., 2010). Furthermore, companies audited by risk-seeking audit partners are likely to defer or even avoid income-decreasing accounting choices (Khrisnan, 2005). We therefore expect client firms of audit partners with criminal convictions to use income-decreasing 
discretionary accruals less extensively in earnings than clients of audit partners without criminal convictions. We also expect client firms of audit partners with criminal convictions to write off smaller proportions of goodwill than client firms audited by audit partners without criminal convictions.

Consistent with Simunic (1980) and others, we also construct control variables that have been found to be associated with the complexity of the audit engagement:

(xi) ROA - Return-on-Assets, measured as net income divided by total assets.

(xii) FOREIGN - The proportion of the client firm's sales generated by foreign operations;

(xiii) EXCEPTION - An indicator variable that obtains a value of "1", if the client firm reports exceptional or extraordinary items, and otherwise "0". The existence of such items often requires special attention by the auditor due to their underlying circumstances; and

(xiv) HIGH_TECH - An indicator variable that obtains a value of "1" if the client firm belongs to a high-tech industry, and otherwise "0". Classification is based on OECD 2-digit SIC code classification (2-digit codes: $28,35,36,37,38,48,73$ and 87, are classified as hightech). High-tech firms increase audit work due to the complexity of their products, production technologies, and the intensity of intangible assets.

In addition, we define two control variables for over-all audit risk:

(xv) LOSS - The natural logarithm of the absolute value of earnings if earnings are negative and otherwise "0". Client firms that report losses are considered riskier for the auditor due to possible litigation or financial distress; and

(xvi) BIG5 - An indicator variable that obtains a value of " 1 " if the firm has a Big-5 auditor, and otherwise "0". While some prior studies suggest that Big-5 auditors accept low-risk 
clients, other studies argue the opposite. Thus, we are unable to predict the sign of the coefficient on this variable.

Finally, according to Prediction 4, audit partners with criminal convictions will charge, on average, higher audit fees. We therefore construct (xvii) LNAUFEE as the natural logarithm of total audit fees, and expect it to be positively associated with the likelihood of appointing an auditor with past criminal convictions.

Table 4 provides descriptive statistics for our three measures of auditor convictions and for the 17 variables discussed above (using 1,588 firm-year observations). We find that $34 \%$ of the companies in our sample have at least one auditor with a criminal conviction (mean CONV_AUD1 $=0.34$ ), and that some firms have up to 3 auditors with criminal convictions $\left(\right.$ maximum $\left.C O N V \_A U D 2=3\right) .{ }^{13}$ Regarding the corporate governance variables, $29 \%$ of board members have criminal convictions, and $29 \%$ of the companies in our sample have a convicted major shareholder. ${ }^{14}$ Also, the percentage of outside directors is, on average, $16 \%$. Note that $90 \%$ of the firms in our sample are audited by Big-5 firms, indicating that appointing auditors with past criminal behavior is not a phenomenon confined to small audit firms.

(Table 4 about here)

Table 5 presents pair-wise correlation coefficients between the main variables. Firms audited by convicted auditors have lower current ratios, higher leverage, and lower coverage ratios, suggesting that these firms have higher financial risk, thereby supporting Prediction 1.

\footnotetext{
${ }^{13}$ The three measures of auditor convictions are highly correlated (pair-wise correlations ranging from 0.79 to 0.93 , not tabulated). We repeated all the analyses with the three measures obtaining very similar results. To save space, we report results using only one measure. Also, it is possible that our auditor crime variables are stable over time and hence not distinguishable from audit-firm fixed effects. To check that, we regressed the three crime variables on five Big-5 audit firm dummy variables (Non-Big-5 firms is the base group). $\mathrm{R}^{2} \mathrm{~s}$ are between $1 \%$ and $2 \%$, indicating that the three crime variables are largely unexplained by audit firm fixed effects.

${ }^{14}$ Since these numbers are based on firm-year observations, they are slightly different from those based on person-level statistics reported in Table 2.
} 
Consistent with Prediction 2, auditors', directors' and main owners' measures of criminal convictions are positively correlated. In addition, firms with convicted auditors pay higher audit fees, supporting Prediction 4.

\section{(Table 5 about here)}

In Table 6 we present the means and medians of selected variables for sub-samples of client portfolios according to the number of criminally convicted audit partners (zero convicted audit partners, one convicted audit partner, two convicted audit partners, and at least one convicted audit partner).

Consistent with Prediction 1, client firms of audit partners with criminal convictions are characterized by higher financial risk. The current ratio is, on average, 1.96 for companies audited by at least one auditor with a criminal conviction, which is lower than the average current ratio, 2.27, for companies audited by auditors without criminal convictions; the difference being statistically significant at the 0.01 level for the mean and at the 0.10 level for the median. Leverage increases with the number of convicted audit partners (from 0.16 to 0.19 if the firm is audited by at least one convicted audit partner), and the difference is significant at the 0.01 level. Also, the interest coverage ratio is, on average, 7.29 for companies with at least one convicted audit partner', lower than the average coverage ratio, 7.90, for companies without convicted audit partners; the difference is statistically significant at the 0.01 level.

We do not find any significant differences in firm size (SIZE) and profitability (ROA) between firms audited by at least one convicted auditors and firms audited by zero convicted auditors. Furthermore, the average market-to-book ratio is lower at the 0.05 level for firms with at least one convicted auditor. 
We find that discretionary accruals $(D I S A C C)$ are larger and the proportion of goodwill writeoffs (WOFFS) is smaller in client firms of audit partners with criminal convictions than in those audited by audit partners without criminal convictions, and the difference is significant at the 0.10 level for the means. However, the medians exhibit no differences.

Turning to measures of governance risk, we find evidence that audit partners with criminal convictions have clients with weaker governance mechanisms. In particular, the proportion of convicted directors increases monotonically with the number of convicted audit partners who audit the firm (the difference between "zero" and "at least one" is significant at the 0.01 level). The probability of having a convicted major shareholder also increases with the number of convicted auditors. This probability is 0.26 when there are zero convicted auditors and 0.40 if there are two or more convicted auditors (significant at the 0.01 level). The proportion of outside directors decreases with the number of convicted auditors, but the difference is not significant at the 0.10 level. Overall, these univariate statistics support Prediction 2, namely audit partners with criminal convictions have, on average, clients with weaker corporate governance. Finally, audit fees increase with the number of convicted auditors, as expected under Prediction 4, and the difference is significant at the 0.01 level.

\section{(Table 6 about here)}

Table 7 presents results for estimating a multivariate logistic regression. The dependent variable is CONV_AUD1 (an indicator variable that obtains a value of " 1 " if at least one audit partner of the firm has a criminal conviction, and otherwise "0"). The set of independent variables includes all client firm characteristics and auditor characteristics discussed earlier. We present results for the entire sample (1,588 firm-years) and for observations with Big-5 auditors (1,425 firm-years), to emphasize that the results are not driven by small audit firms. The results 
for firm-years with Non-Big-5 firms (163 observations) are generally weaker due to the small sample, and are hence not reported in a table. The model is estimated with year and industry fixed effects: ${ }^{15}$

$$
\begin{aligned}
& \text { CONV_AUD1 } 1_{j t}=\beta_{0}+\beta_{1} \text { CURRENT }_{j t}+\beta_{2} \text { LEVERAGE }_{j t}+\beta_{3} \text { COVERAGE }_{j t}+\beta_{4} \text { SIZE }_{j t} \\
& +\beta_{5} \text { PB }_{j t}+\beta_{6} \text { ROA }_{j t}+\beta_{7} \text { DISACC }_{j t}+\beta_{8} \text { WOFFS }_{j t}+\beta_{9} \text { CONV_DIR }_{j t}+\beta_{10} \text { CONV_OWNER }_{j t} \\
& +\beta_{11} \text { OUT_DIR }_{j t}+\beta_{12} \text { LNAUFEE }_{j t}+\beta_{13} \text { FOREIGN }_{j t}+\beta_{14} \text { EXCEPTION }_{j t}+\beta_{15} \text { LOSS }_{j t} \\
& +\beta_{16} \text { HIGH_TECH }_{j t}+\beta_{17} \text { AGE } \\
& j t
\end{aligned}
$$

Focusing initially on financial risk, the coefficients for CURRENT, LEVERAGE and COVERAGE have the predicted sign, but only the coefficient on COVERAGE is significant at the 0.10 level for the entire sample. The Vuong test shows that including financial risk measures (CURRENT, LEVERAGE and COVERAGE) jointly improves the model performance at the 0.10 level or better. Collectively, these results support Prediction 1. The coefficient on SIZE is negative, as expected, and significant at the 0.01 level in both regressions, suggesting that smaller firms are more likely to appoint an auditor with a criminal conviction.

The coefficients on discretionary accruals $(D I S A C C)$ are positive, as expected, and the coefficients on goodwill writeoffs (WOFFS) are negative, as expected; all are significant at the 0.10 level or better. This result suggests that the quality of earnings is lower for firms audited by audit partners with criminal convictions, therefore supporting Prediction 3.

Focusing on the three corporate governance variables, we find positive coefficients, as expected, on both $C O N V_{-} D I R$ (the proportion of convicted directors) and CONV_OWNER (the firm has at least one convicted main shareholder); both are significant at the 0.10 level or better. In addition, the coefficient on $O U T_{-} D I R$ (the proportion of outside directors with three of more

\footnotetext{
${ }^{15}$ We estimated the model with audit firm fixed-effects and the results are very similar to those reported in the paper. We also estimated the model with firm fixed-effects but the model is not identifiable.
} 
board memberships of listed Swedish firms) is negative, as expected, and significant at the 0.01 level in both regressions. The Vuong test shows that the inclusion of the governance measures $\left(C O N V_{-} D I R, C O N V_{-} O W N E R\right.$ and $\left.O U T_{-} D I R\right)$ jointly improves the model performance at the 0.01 level. These results support Prediction 2 - companies with weaker corporate governance are more likely to appoint audit partners with criminal convictions. In support of Prediction 4, companies that are audited by convicted/suspected audit partners pay higher audit fees, as reflected in the positive coefficient on LNAUFEE (significant at the 0.01 level).

Also, consistent with our previous results, auditors with criminal convictions tend to me older males, as reflected by the positive coefficients on $A G E$ and GENDER. Consistent with the results of the audit partner level analyses in Table 3, we find a negative coefficient on the indicator variable for Big-5 audit firms suggesting that client firms having convicted auditors use Big-5 audit firms; however, this coefficient is not significant at the 0.10 level. Finally, the coefficients on the market-to-book ratios $(P B)$, return-on-assets $(R O A)$, the proportion of sales generated by foreign operations (FOREIGN), the existence of exceptional items (EXCEPTION), losses (LOSS), an indicator variable for high-tech firms, and the number of audit engagements (CLIENTS) are all not significant at the 0.10 level. ${ }^{16}$

(Table 7 about here)

\subsection{Audit Partners' Criminal Convictions and Accounting Conservatism}

According to Prediction 3, financial statements audited by audit partners with criminal convictions are expected to exhibit a lower degree of conditional conservatism. To test this

\footnotetext{
${ }^{16}$ We estimated the models in Tables 7, 8 and 9 without the crime convictions under codes 1972:603 and 1998:1276 (see Table 1). The results become slightly stronger than those currently reported, which is consistent with the view that some criminal convictions may be less indicative of risk-taking behavior than others.
} 
prediction, we use Basu's (1997) framework in a manner similar to Krishnan (2005). Specifically we estimate Equation (3):

$$
\begin{aligned}
& E P_{j t}=\delta_{0}+\delta_{1} R E T_{j t}+\delta_{2} D_{R E T_{j t}}+\delta_{3} R E T_{j t} \times D R E T_{j t}+\delta_{4} C O N V_{-} A U D 2_{j t}+\delta_{5} R E T_{j t} \times C O N V_{-} A U D 2_{j t} \\
& +\delta_{6} D_{R E T} \times C O N V_{-} A U D 2_{j t}+\delta_{7} R E T_{j t} \times D R E T_{j t} \times C O N V_{-} A U D 2_{j t}+\delta_{8} S I Z E_{j t}+\delta_{9} L E V E R A G E_{j t} \\
& +\delta_{10} P B_{j t}+\delta_{11} R E T_{j t} \times S I Z E_{j t}+\delta_{12} R E T_{j t} \times L E V E R A G E_{j t}+\delta_{13} R E T_{j t} \times P B_{j t}+\delta_{14} D R E T_{j t} \times S I Z E_{j t} \\
& +\delta_{15} D^{2} E T_{j t} \times L E V E R A G E_{j t}+\delta_{16} D R E T_{j t} \times P B_{j t}+\delta_{17} R E T_{j t} \times D R E T_{j t} \times S I Z E_{j t} \\
& +\delta_{18} R E T_{j t} \times D R E T_{j t} \times L E V E R A G E_{j t}+\delta_{19} R E T_{j t} \times D R E T_{j t} \times P B_{j t}+v_{j t} .
\end{aligned}
$$

$E P_{j t}$ is earnings per share divided by beginning-of-the-year share price; $R E T_{j t}$ is annual stock return; $D R E T_{j t}$ is an indicator variable obtaining a value of " 1 " if $R E T_{j t}$ is negative, and otherwise " 0 "; and $C O N V \_A U D 2_{j t}$ is a variable measuring the number of convicted audit partners auditing a firm. Equation (3) also includes controls for firm size (SIZE), financial leverage (LEVERAGE) and market-to-book ratios $(P B)$ and their respective interactions, as well as fixed firm and year effects. We estimate Equation (3) by using our three alternative measures of convicted audit partners obtaining similar results, hence, Table 8 reports results obtained with $C O N V_{-} A U D 2_{j t}$ (the number of convicted audit partners auditing firm $i$ in year $t$ ). Finally, we present the results for the entire sample (1,588 observations) and for firm-year observations audited by Big-5 firms.

A positive coefficient on $R E T \times D R E T$ would suggest that bad economic news are incorporated in earnings more timely than good news. A negative coefficient on $R E T \times D R E T \times C O N V_{-} A U D 2$ would suggest that firms audited by auditors with criminal convictions exhibit a lower degree of conditional conservatism than other firms. A positive coefficient on $R E T \times C O N V_{-} A U D 2$ would suggest that the earnings of firms using convicted auditors reflect positive news more timely than firms not using them.

The results in Table 8 suggest that firms in our sample exhibit, on average, accounting conservatism, as reflected by the positive coefficient on RET $\times$ DRET (significant at the 0.01 
level in both regressions). In addition, the coefficient on $R E T \times D R E T \times C O N V_{-} A U D 2$ is negative, as expected under Prediction 3, and significant at the 0.05 level. This result suggests that firms audited by audit partners with criminal convictions exhibit a lower degree of accounting conservatism. This result is corroborated by the positive coefficients on RETx $C O N V_{-}$AUD2 (significant at the 0.05 level), suggesting that positive information is reflected in accounting earnings faster when the financial statements are audited by audit partners with

criminal convictions. Overall, the results in Table 8 support Prediction 3, namely audit partners with criminal convictions exercise a lower degree of accounting conservatism. This lower degree of accounting conservatism also supports our argument that auditors with criminal convictions are less concerned with accounting conservatism because they are willing to assume higher audit risk when accepting clients. These results are not driven by auditors employed in small audit firms, as exhibited by the model estimated with firm-year observations audited by large audit firms.

(Table 8 about here)

\subsection{Audit Partners' Criminal Convictions and Audit Fees}

Our analyses in Tables 5-7 suggest that firms audited by auditors with criminal convictions pay higher audit fees, as expected under Prediction 4. However, these results reflect the higher audit risk of the client firms audited by audit partners with criminal convictions. To test whether audit partners charge a lower fee per unit of audit risk (Prediction 5), we construct the following audit pricing model (Simunic, 1980): 


$$
\begin{aligned}
& \text { LNAUFEE }_{j t}=\gamma_{0}+\gamma_{1} \text { CONV_AUD }_{j t}+\gamma_{2} \text { CURRENT }_{j t}+\gamma_{3} \text { LEVERAGE }_{j t} \\
& +\gamma_{4} \text { COVERAGE }_{j t}+\gamma_{5} \text { PB }_{j t}+\gamma_{6} \text { SIZE }_{j t}+\gamma_{7} \text { ROA }_{j t}+\gamma_{8} \text { FOREIGN }_{j t}+\gamma_{9} \text { EXCEPTION }_{j t} \\
& +\gamma_{10} \text { LOSS }_{j t}+\gamma_{11} \mathrm{HIGH}_{-} \mathrm{TECH}_{j t}+\gamma_{12} \text { BIG }_{j t}+\gamma_{13} \mathrm{CURRENT}_{j t} \times \mathrm{CONV}{ }_{-} \text {AUD2 } 2_{j t} \\
& +\gamma_{14} \text { LEVERAGE }_{j t} \times C O N \text { COND }_{j t}+\gamma_{15} \text { COVERAGE }_{j t} \times C O N \text { CON }_{-} \text {AUD2 } 2_{j t} \\
& +\gamma_{16} P B_{j t} \times C O N V_{-} A U D 2_{j t}+\gamma_{17} S I Z E_{j t} \times C O N V_{-} A U D 2_{j t}+\vartheta_{j t} .
\end{aligned}
$$

The dependent variable is the log of audit fees (LNAUFEE) for client firm $j$ in year $t$. The first independent variable of interest is whether the firm is audited by audit partners with criminal convictions ( $\left.C O N V \_A U D 2\right)$. As described earlier, we use three alternative measures for auditors' criminal behavior (CONV_AUD1,CONV_AUD2 and $\left.C O N V_{-} A U D 3\right)$. These variables yield qualitatively similar results, so we report only the results with $C O N V \_A U D 2$ as an independent variable. According to Prediction 4, the coefficient on this variable is expected to be positive.

The next five explanatory variables are financial and overall risk measures: Current ratio (CURRENT), financial leverage ( $L E V E R A G E)$, interest coverage ratio (COVERAGE), the priceto-book ratio $(P B)$, and the natural logarithm of total assets (SIZE). We expect audit fees to decrease with interest coverage (COVERAGE) and short-term liquidity (CURRENT), and increase with market-to-book ratios $(P B)$, firm size (SIZE) and financial leverage (LEVERAGE).

We also include in Equation (4) six control variables that capture audit complexity: Return on assets (ROA), the proportion of foreign sales (FOREIGN), an indicator for exceptional and extraordinary items (EXCEPTION), the logarithm of the absolute value of earnings if earnings are negative and otherwise "0" (LOSS), an indicator of high-tech industries (HIGH_TECH), and for the entire sample, an indicator of Big-5 audit firms (BIG5). We expect audit fees to decrease with profitability $(R O A)$. We also expect audit fees to increase with the proportion of foreign operations $(F O R E I G N)$, as multinational firms require additional audit resources. The existence 
of exceptional and/or extraordinary items (EXCEPTION) also requires special attention, which is expected to result in higher audit fees. Auditing technology-based companies (HIGH_TECH) is likely to increase the amount of work required for rigorous auditing of intangibles and may also increase the risk of litigation against the auditor and hence increase audit fees. Furthermore, losses (LOSS) increase an auditor's risk and, consequently, audit fees. Finally, Big-5 audit firms (BIG5) are expected to charge additional fees as a premium for their reputation.

To test whether audit partners with criminal convictions charge a lower fee per unit of risk, we add to Equation (4) five interaction variables. Each one is a multiplication of CONV_AUD2 with one of the five risk measures (CURRENT, LEVERAGE, COVERAGE, PB, and SIZE). According to Prediction 5, the coefficients on these variables are expected to be opposite to those on the main effects.

We estimate Equation (4) using fixed firm and year effects and clustered standard errors as in Petersen (2009). Due to the inclusion of interaction variables and firm fixed effects, which are highly correlated, we estimate Equation (4) with one risk interaction variable at the time. We present results for the entire sample (1,588 observations) and for those firm-year observations audited by Big-5 firms (1,425 observations).

The results in Table 9 show a positive association between audit fees paid by clients and audit partners' criminal convictions, as reflected by the positive coefficient on CONV_AUD2 (significant at the 0.05 level in the entire sample, and at the 0.10 level for Big-5 firms). This result supports Prediction 4 in that firms audited by convicted audit partners pay higher audit fees than other firms. The coefficients on the five interaction variables have the predicted sign, 
and the interactions with $L E V E R A G E$ and COVERAGE are significant at the 0.10 level or better. ${ }^{17}$ These results provide some support for Prediction 5.

All the coefficients on the control variables have the predicted sign, but only the coefficients on CURRENT, COVERAGE, SIZE, ROA, EXCEPTION, and HIGH_TECH are significant at the 0.10 level or better. Overall, results in Table 9, which support Predictions 4 and 5, suggest that audit partners with criminal convictions charge higher fees, on average, but they charge a lower fee per unit of risk.

\section{(Table 9 about here)}

In addition, we identified 28 cases where auditors with criminal convictions replaced auditors without criminal convictions, and 35 cases where auditors without criminal convictions replaced those with criminal convictions. Then we measured the average natural logarithm of audit fees in the three years before and the three years after the auditor replacement. Consistent with Prediction 4, we find (results not tabulated) that audit fees increase (at the 0.01 level using a $t$-test on the paired differences) following appointments of auditors with criminal convictions. When auditors with criminal convictions are replaced by those without criminal convictions, audit fees remain stable on average. Although the sample of changes is quite small, this result lends support to Prediction 4, because as DeAngelo (1981) argues, audit fees are expected to decline, not to increase, due to low balling.

\footnotetext{
${ }^{17}$ We estimated the model with the five interaction variables and performed $\mathrm{F}$ tests that all the five coefficient are equal to zero. The F statistic for the entire sample is 3.03, significant at the 0.01 level; for the model with Big-5 observations the F statistic is 3.55, also significant at the 0.01 level. The null hypothesis that the coefficients on the interaction variables are all equal to zero is therefore rejected at the 0.01 level.
} 


\section{Summary and Conclusions}

We explore how audit partners' personal risk preferences affect their client portfolio risk. We argue that audit partners' crime convictions reflect their propensity to take audit risk, and predict that the client firms of audit partners with criminal convictions have greater financial, governance and financial reporting risk than those of audit partners without criminal convictions. We contribute to the debate on how auditors' personal characteristics affect the audit engagement by relaxing the assumption often made in auditing research that auditors are homogenous individuals with similar personal characteristics. Our empirical findings support the argument that the auditing process, the decisions taken during this process, and audit pricing are affected by the auditor's personal characteristics.

Our results of analyzing a unique dataset on Swedish auditors' criminal convictions show that audit partners with criminal convictions are willing to engage in riskier audits than those without criminal convictions. In particular, the results show that client firms of audit partners with criminal convictions have a greater financial risk, weaker governance system, and less conservative financial reporting than those of audit partners without criminal convictions. We measure financial risk using standard financial ratios and the governance risk of the client by using measures of board characteristics; as a measure of financial reporting risk, we employ the conditional earnings conservatism of Basu (1997).

In addition, we examine the audit fees charged by audit partners with and without criminal convictions. We find support for the prediction that audit fees in audits performed by audit partners with criminal convictions are, on average, higher than those audits performed by auditors without criminal convictions. We interpret this result as an economic compensation charged by the auditor (paid by the client firm) for assuming additional financial, governance 
and reporting risk. We also find some evidence suggesting that audit partners with criminal convictions charge a lower fee per unit of risk.

These findings have several implications for future research. First, a measure of auditors' risk tolerance based on audit firm size is incomplete, and could also be misleading. An auditor with a criminal conviction employed by a large audit firm is likely to accept riskier clients than an auditor with a clean record employed by a small audit firm. Second, our study suggests that results in studies using data at the firm or office level could change if data on individual auditors become available. Our study also contributes to the debate in the United States on whether firms should disclose the identity of the auditor in charge of the audit engagement, as suggested by the PCAOB. Our findings indirectly support those who claim that requiring audit partners to sign their names on financial statements would enhance the transparency of financial statements. As for policy implications, our results suggest that regulators concerned with auditors' propensity to take audit risk should focus more on individual auditors' personal background. 


\section{References}

Becker, G.S. (1968), Crime and Punishment: An Economic Approach, Journal of Political Economy, vol. 78, no. 2, pp. 169-217.

Basu, S (1997), The conservatism principle and asymmetric timeliness of earnings, Journal of Accounting and Economics, vol. 24, no. 1, pp. 3-37.

Basu, S., L. Hwang, and C-L. Jan (2001), Differences in conservatism between big-8 and nonbig-8 auditors, Working paper, CUNY Baruch and California State University.

Blickle, G., A. Schlegel, P. Fassbender, and U. Klein (2006), Some personality correlates of business white-collar crime, Applied Psychology: An International Review, vol. 55, pp. 220-233.

Chen, S., S.Y.J. Sun, and D. Wu (2010), Client Importance, Institutional Improvements, and Audit Quality in China: An Office and Individual Auditor Level Analysis, The Accounting Review, vol. 85, no. 1, pp. 127-158.

Chin, C-L., and H-Y Chi (2008), Sex Matters: Gender Differences in Audit Quality, Working paper, the 2008 Meeting of the American Accounting Association (August), Anaheim.

Choi, J.H., J.B. Kim, X. Liu, and D. Simunic (2008), Audit pricing, legal liability regimes, and Big 4 premiums: Theory and cross-country evidence, Contemporary Accounting Research, vol. 25, no. 1, pp. 1-49.

Cohen, J. R, and D. M. Hanno (2000), Auditors' consideration of corporate governance and management control philosophy in preplanning and planning judgments, Auditing: A Journal of Practice and Theory, vol. 19, pp. 133-146.

Cohen, J.R., and G.M. Trompeter (1998), An examination of factors affecting audit practice development, Contemporary Accounting Research, vol. 15, n. 4, pp. 481-504.

Daly, K. (1989), Gender and varieties of white-collar crime, Criminology, vol. 27, no. 4, pp. 769-794.

DeAngelo, L. E. (1981), 'Auditor independence, "low balling” and disclosure regulation', Journal of Accounting \& Economics, vol. 3, pp. 113-27.

Dechow, P., W. Ge, and C. Schrand (2010), Understanding Earnings Quality: A Review of the Proxies, their Determinants and their Consequences, Journal of Accounting and Economics, 2010, vol. 50, nos. 2-3 (December).

Ehrlich, I. (1973), Participation in illegitimate activities: A theoretical and empirical investigation, Journal of Political Economy, vol. 81, no. 3, pp. 521-565. 
Eide, E., P.H. Rubin, and J.M. Shepherd (2006), Economics of crime, Foundations and trends in Microeconomics 2:3, now Publishers, Hanover, US.

Farmer, T. A. (1993), Testing the effect of risk attitude on auditor judgment using multiattribute utility theory. Journal of Accounting, Auditing \& Finance, vol. 8 (Winter), pp. 91-110.

Fisman, R. and E. Miguel (2007), Corruption, Norms, and Legal Enforcement: Evidence from UN Diplomatic Parking Tickets. Journal of Political Economy, vol. 115, no. 61, pp. 1020-1048.

Francis, J. R. (2011), A framework for understanding and researching audit quality, Auditing: A Journal of Practice \& Theory, vol. 30 (May), pp. 125-152.

Francis, J. R., and J. Krishnan (2002), Evidence on Auditor Risk-Management Strategies Before and After the Private Securities Litigation Reform Act of 1995, Asia-Pacific Journal of Accounting and Economics, vol. 9, pp. 135-57

Garoupa, N., (2003), Behavioral Economic Analysis of Crime: A Critical Review, European Journal of Law and Economics, vol. 15, pp. 5-15.

Grinblatt, M., and M. Keloharju (2009), Sensation seeking, overconfidence and trading activity. Journal of Finance, vol. 64, pp. 549-578.

Hribar, P., T.D. Kravet and R.J. Wilson (2010), A New Measure of Accounting Quality, working paper available at SSRN: http://ssrn.com/abstract=1283946

Iversen, H., and T. Rundmo (2002), Personality, Risky Driving and Accident Involvement among Norwegian Drivers, Personality and Individual Differences, vol. 33, pp. 1251-1263.

Jones, J. J. (1991), Earnings Management during Import Relief Investigation. Journal of Accounting Research, vol. 29, no. 2, pp. 193-228.

Junger, M., R. West, and R. Timman (2001), Crime and Risky Behavior in Traffic: An Example of Cross-Situational Consistency, Journal of Research in Crime and Delinquency, vol. 38, pp. 439-459.

Johnstone, K. M. (2000), Client-Acceptance Decisions: Simultaneous Effects of Client Business Risk, Audit Risk, Auditor Business Risk, and Risk Adaptation, Auditing: A Journal of Practice \& Theory, vol. 19 (Spring), pp. 1-25.

Jones, F. L., and K. Raghunandan (1998), Client Risk and Recent Changes in the Market for Audit Services, Journal of Accounting and Public Policy, vol. 17, pp. 169-81.

Kahneman, D., and A. Tversky (1979), Prospect Theory: An analysis of decision under risk, Econometrica, vol. 47 (March), pp. 263-91. 
Kennedy, J., and M.E. Peecher (1997), Judging auditors' technical knowledge, Journal of Accounting Research, vol. 35, no. 2, pp. 279-292.

Korsell, L. (2001), Three decades of researching and combating economic crime - the Swedish case, in Lindgren, S.A. (ed.), White-Collar Crime Research. Old Views and Future Potentials, Stockholm, The National Council for Crime Prevention, pp. 91-106.

Krishnan, G.V. (2005), Did Houston clients of Arthur Andersen recognize publicly available bad news in a timely manner? Contemporary Accounting Research, vol. 22, no. 1, pp. 165-193.

McKenna, F.P. (1993), It won't happen to me: unrealistic optimism or illusion of control?, British Journal of Psychology, vol. 84, pp. 39-50.

Messier, W.F., V. Owhoso, and C. Rakovski (2008), Can Audit Partners Predict Subordinates' Ability to Detect Errors? Journal of Accounting Research, vol. 46, no. 5, pp. 1241-1264.

Palmer and Hollin (2004), Predicting reconviction using the Psychological Inventory of Criminal Thinking Styles with English prisoners, Legal and Criminological Psychology, vol. 9, pp. 57-68.

Pratt, J., and J. D. Stice (1994), The effects of client characteristics on auditor litigation risk judgments, required audit evidence, and recommended audit fees. The Accounting Review, vol. 69, pp. 639-656.

Petersen, M.A. (2009), Estimating standard errors in finance panel data sets: Comparing approaches, Review of Financial Studies, vol. 22, pp. 435-480.

Public Company Accounting Oversight Board (2009), Seven year of the Public Company Accounting Oversight Board: What has been accomplished and what remains to be done. Address to the AICPA National Conference on SEC and PCAOB developments (December $7^{\text {th }}$ ).

Qiang, X. (2007), The effects of contracting, litigation, regulation, and tax costs on conditional and unconditional conservatism: cross-sectional evidence at firm level. The Accounting Review, vol. 82 (3), pp. 759-796.

Reynolds ,J.K. and J. Francis (2000), Does size matter? The influence of large clients on officelevel auditor reporting decisions, Journal of Accounting and Economics, vol. 30, pp. 375-400.

Sandroni, A., and F. Squintani (2004), A survey on overconfidence, insurance and selfassessment training programs, Working Paper, Kellogg School of Management.

Schatzberg, J.W., G.R. Sevcik, B.P., Shapiro, L. Thorne, and R.S.O. Wallace (2005), A Reexamination of Behavior in Experimental Audit Markets: The Effects of Moral Reasoning and Economic Incentives on Auditor Reporting and Fees, Contemporary Accounting Research, vol. 22, no 1, pp. 229-264. 
Simunic, D.A. (1980), The pricing of audit services: Theory and evidence, Journal of Accounting Research, vol. 18, no. 1, pp. 161-190.

Simunic, D.A. and M.T. Stein (1990), Audit risk in a client portfolio context, Contemporary Accounting Research, vol. 6, no. 2 (Spring): 329-343.

Skinner, D. J. 1997. Earnings disclosures and stockholder lawsuits. Journal of Accounting and Economics, vol. 23 (1), pp. 249-282.

Walters, G.D. (2009), The psychological inventory of criminal thinking styles and psychopathy checklist: screening version as incrementally valid predictors of recidivism, Law and Human Behavior, vol. 33, pp. 497-505.

Watts, R. (2003), Conservatism in accounting part II: Evidence and Research Opportunities, Accounting Horizons, vol. 17, no. 4, pp. 287-301.

Zahra, R., L. Priem, and A.M.A. Rasheer (2005), The antecedents and consequences of top management fraud, Journal of Management, vol. 31, pp. 803-828. 


\section{Table 1 \\ Laws Violated by Auditors in the Sample}

\begin{tabular}{|c|c|c|c|c|c|c|}
\hline \multirow[t]{2}{*}{ Code } & \multirow[t]{2}{*}{ Title } & \multicolumn{3}{|c|}{ Convictions } & \multirow[t]{2}{*}{ Example } & \multirow{2}{*}{$\begin{array}{c}\text { Penalty } \\
\text { Range }\end{array}$} \\
\hline & & All & Big-5 & $\begin{array}{r}\text { Non } \\
\text {-Big-5 }\end{array}$ & & \\
\hline 1951:649 & $\begin{array}{l}\text { Act on Criminal } \\
\text { Responsibility for Certain } \\
\text { Traffic Offences }\end{array}$ & 14 & 11 & 3 & $\begin{array}{l}\text { Drunken or reckless } \\
\text { driving }\end{array}$ & $\begin{array}{l}\text { Fines to } 2 \\
\text { years in } \\
\text { prison }\end{array}$ \\
\hline 1972:603 & Road Traffic Promulgation & 14 & 10 & 4 & $\begin{array}{l}\text { Various traffic-related } \\
\text { crimes, all types of } \\
\text { vehicles }\end{array}$ & Fines \\
\hline 1998:1276 & Vehicle Ordinance & 7 & 6 & 1 & $\begin{array}{l}\text { Various traffic related } \\
\text { crimes, all kinds of } \\
\text { vehicles }\end{array}$ & Fines \\
\hline $\begin{array}{l}\text { Penal Code } \\
\text { Chapter } 8\end{array}$ & $\begin{array}{l}\text { Theft, robbery, other } \\
\text { stealing }\end{array}$ & 5 & 4 & 1 & Shoplifting, robbery & $\begin{array}{l}\text { Fines to } 10 \\
\text { years in } \\
\text { prison }\end{array}$ \\
\hline $\begin{array}{l}\text { Other Penal } \\
\text { Code } \\
\text { crimes }\end{array}$ & $\begin{array}{l}\text { Fraud, Other Acts of } \\
\text { Dishonesty, Crimes } \\
\text { Inflicting Damage }\end{array}$ & 4 & 4 & $\mathbf{0}$ & $\begin{array}{l}\text { Fraud, Damage to public } \\
\text { property }\end{array}$ & $\begin{array}{l}\text { Up to } 6 \\
\text { years in } \\
\text { prison }\end{array}$ \\
\hline 1960:418 & $\begin{array}{l}\text { Act on Criminal } \\
\text { Responsibility for } \\
\text { Smuggling }\end{array}$ & 2 & 2 & $\mathbf{0}$ & $\begin{array}{l}\text { Importing/Exporting } \\
\text { goods w/out payment of } \\
\text { duty or other taxes }\end{array}$ & $\begin{array}{l}\text { Fines to } 6 \\
\text { years in } \\
\text { prison }\end{array}$ \\
\hline & All other crimes & 7 & 6 & 1 & & \\
\hline Auditors w & a crime convictions & 53 & 43 & 10 & & \\
\hline Suspected o & crimes & 7 & 7 & $\mathbf{0}$ & & \\
\hline Total convi & ed/Suspected & 60 & 50 & 10 & & \\
\hline Total Samp & & 482 & 431 & 51 & & \\
\hline Percentage & f total sample & $12.4 \%$ & $11.6 \%$ & $19.6 \%$ & & \\
\hline
\end{tabular}

*Notes:

1. The sample includes 482 Swedish auditors who audited publicly listed firms in Sweden in at least one year during the sample period (1999-2007). 431 of these individuals were employed by Big-5, and 51 were employed in Non-Big-5 firms.

2. Data on auditors' criminal convictions are taken from Brå (The Swedish National Council for Crime Prevention). This dataset contains information on individual auditors who have been found guilty by a court of law or received summary punishments by prosecutors since 1974.

3. Data on suspected criminal actions relate to auditors who have been investigated in connection with serious crimes since 1991, but the prosecutor eventually decided not to pursue the case in court. The database is maintained by the Swedish National Police Board. 
Table 2

Crime Frequencies for Auditors, Directors, CEOs and Main Owners*

\begin{tabular}{lccccc}
\hline & \multicolumn{2}{c}{ Convicted and/or Suspected } & $\begin{array}{c}\text { Not Convicted } \\
\text { nor Suspected }\end{array}$ & Total \\
\cline { 2 - 5 } & $\begin{array}{c}\text { Suspected } \\
\text { and } \\
\text { Convicted }\end{array}$ & $\begin{array}{c}\text { Suspected } \\
\text { but not } \\
\text { Convicted }\end{array}$ & All & & \\
\hline Auditors & 53 & 7 & 60 & 422 & 482 \\
Board of Directors & $(11.0 \%)$ & $(1.5 \%)$ & $(12.4 \%)$ & $(87.6 \%)$ & $(100 \%)$ \\
CEOs & 687 & 122 & 809 & 2,338 & 3,147 \\
Main Owners & $(21.8 \%)$ & $(3.9 \%)$ & $(25.7 \%)$ & $(74.3 \%)$ & $(100 \%)$ \\
& 156 & 20 & 176 & 355 & 531 \\
& $(29.4 \%)$ & $(3.8 \%)$ & $(33.1 \%)$ & $(66.9 \%)$ & $(100 \%)$ \\
& 112 & 17 & 129 & 167 & 296 \\
& $(37.8 \%)$ & $(5.7 \%)$ & $(43.6 \%)$ & $(56.4 \%)$ & $(100 \%)$ \\
\hline
\end{tabular}

*Note: The table presents the number of individuals and proportions of convicted/suspected auditors, directors, CEOs and main owners in Swedish listed companies. The sample of auditors includes all auditors of Swedish listed companies in Sweden. The samples of board members CEOs, and main owners include all directors, CEOs and shareholders who hold at least $10 \%$ of equity in the 293 industrial Swedish listed companies for which we could access financial data. 


\section{Table 3}

\section{Characteristics of Convicted, Suspected and Other Auditors*}

Panel A: Descriptive statistics for personal characteristics variables $(\mathrm{N}=482)$ :

\begin{tabular}{lrrrrr}
\hline Variable & Mean & Median & \multicolumn{1}{c}{ Std } & \multicolumn{1}{c}{ Min } & \multicolumn{1}{c}{ Max } \\
\hline GENDER & 0.83 & 1.00 & 0.38 & 0.00 & 1.00 \\
AGE & 47.30 & 47.25 & 8.54 & 24.00 & 78.50 \\
CLIENTS & 7.74 & 4.00 & 8.97 & 1.00 & 60.00 \\
BIG_AUD & 0.86 & 1.00 & 1.10 & 0.00 & 1.00 \\
\hline
\end{tabular}

Panel B: Means/Medians by categories of criminal activity:

\begin{tabular}{|c|c|c|c|c|c|}
\hline \multirow[t]{2}{*}{ Variable } & \multicolumn{3}{|c|}{ Convicted/Suspected Auditors } & \multirow{2}{*}{$\begin{array}{c}\begin{array}{c}\text { Other } \\
\text { Auditors }\end{array} \\
(\mathrm{N}=\mathbf{4 2 2})\end{array}$} & \multirow{2}{*}{$\begin{array}{c}\text { Difference } \\
\text { between } \\
\text { 'Total' and } \\
\text { 'Other auditors' }\end{array}$} \\
\hline & $\begin{array}{c}\text { Convicted } \\
(N=53)\end{array}$ & $\begin{array}{l}\text { Suspected } \\
(\mathbf{N}=7)\end{array}$ & $\begin{array}{c}\text { Total } \\
(\mathbf{N}=60)\end{array}$ & & \\
\hline & $\begin{array}{c}\text { Mean } \\
\text { Median }\end{array}$ & $\begin{array}{c}\text { Mean } \\
\text { Median }\end{array}$ & $\begin{array}{c}\text { Mean } \\
\text { Median }\end{array}$ & $\begin{array}{c}\text { Mean } \\
\text { Median }\end{array}$ & $\begin{array}{c}\text { t-test } \\
\text { Wilcoxon-test }\end{array}$ \\
\hline GENDER & $\begin{array}{l}0.96 \\
1.00\end{array}$ & $\begin{array}{l}0.86 \\
1.00\end{array}$ & $\begin{array}{l}0.95 \\
1.00\end{array}$ & $\begin{array}{l}0.81 \\
1.00\end{array}$ & $\begin{array}{l}2.69++ \\
2.67++\end{array}$ \\
\hline$A G E$ & $\begin{array}{l}50.19 \\
50.50\end{array}$ & $\begin{array}{l}46.89 \\
47.67\end{array}$ & $\begin{array}{l}49.80 \\
50.50\end{array}$ & $\begin{array}{l}46.95 \\
47.00\end{array}$ & $\begin{array}{c}2.44+ \\
2.49++\end{array}$ \\
\hline CLIENTS & $\begin{array}{r}10.15 \\
6.00\end{array}$ & $\begin{array}{r}10.14 \\
7.00\end{array}$ & $\begin{array}{r}10.15 \\
7.00\end{array}$ & $\begin{array}{l}7.40 \\
4.00\end{array}$ & $\begin{array}{l}2.23+ \\
2.23+\end{array}$ \\
\hline$B I G \_A U D$ & $\begin{array}{l}0.77 \\
1.00\end{array}$ & $\begin{array}{l}0.86 \\
1.00\end{array}$ & $\begin{array}{l}0.78 \\
1.00\end{array}$ & $\begin{array}{l}0.87 \\
1.00\end{array}$ & $\begin{array}{l}-1.95 * \\
-2.00+\end{array}$ \\
\hline
\end{tabular}

*Notes:

1. Panel A presents descriptive statistics for variables capturing audit partners' personal characteristics. Panel B presents mean and median variables for sub-samples of convicted audit partners (53 individuals), suspected audit partners (7 individuals) and nonconvicted/suspected audit partners (422 individuals). Panel B of the table also presents results for two statistical tests for the difference in means (t-test) and medians (Wilcoxon test) between the sample of convicted/suspected audit partners and those audit partners not convicted/suspected.

2. Data on criminal convictions contain information on individual auditors who have been found guilty by a court of law or received summary punishments by prosecutors since 1974 . Data on suspected criminal actions relate to auditors who have been investigated in 
connection with serious crimes since 1991, but the prosecutor eventually decided not to pursue the case in court. The database is maintained by the Swedish National Police Board.

3. For each audit partner, we identify key variables that capture personal characteristics. These variables are defined as follows:

- GENDER - An indicator variable that is equal to " 1 " if the audit partner is a male and " 0 " if a female.

- $A G E$ - The age of the audit partner in the middle of the sample period from 1999 to 2007.

- CLIENTS - The number of client-years audited by an audit partner during the sample period.

- $B I G \_A U D$ - An indicator variable that obtains a value of "one" if the audit partner is employed by a Big-5 audit firms (Ernst \& Young, KPMG, PWC, Deloitte and Arthur Andersen) and "zero" for other audit firms. If an audit partner has switched between Big-5 and Non-Big-5 audit firms during the sample period, we take the average of the yearly observations of this variable over the sample period.

4.,,$+++ *$ denote significance levels at the $0.01,0.05$ and 0.10 levels respectively. 
Table 4

Summary Statistics of Client Firms (1,588 firm-year observations)*

\begin{tabular}{lrrrrr}
\hline Variable & Mean & \multicolumn{1}{c}{ Median } & \multicolumn{1}{c}{ Std } & \multicolumn{1}{c}{ Min } & \multicolumn{1}{c}{ Max } \\
\hline CONV_AUD1 & 0.34 & 0.00 & 0.47 & 0.00 & 1.00 \\
CONV_AUD2 & 0.38 & 0.00 & 0.57 & 0.00 & 3.00 \\
CONV_AUD3 & 0.19 & 0.00 & 0.34 & 0.00 & 1.00 \\
CURRENT & 2.16 & 1.74 & 1.61 & 0.23 & 11.80 \\
LEVERAGE & 0.17 & 0.15 & 0.15 & 0.00 & 0.60 \\
COVERAGE & 7.69 & 7.65 & 3.02 & -1.88 & 16.58 \\
SIZE & 6.80 & 6.57 & 2.02 & 1.35 & 12.23 \\
PB & 2.87 & 2.15 & 2.39 & 0.29 & 17.06 \\
& & & & & \\
CONV_DIR & 0.29 & 0.26 & 0.19 & 0.00 & 1.00 \\
CONV_OWNER & 0.29 & 0.00 & 0.45 & 0.00 & 1.00 \\
OUT_DIR & 0.16 & 0.14 & 0.16 & 0.00 & 1.00 \\
BIG5 & 0.90 & 1.00 & 0.30 & 1.00 & 1.00 \\
& & & & & \\
ROA & 0.01 & 0.06 & 0.20 & -0.99 & 0.41 \\
FOREIGN & 0.25 & 0.00 & 0.33 & 0.00 & 1.00 \\
EXCEPTION & 0.28 & 0.00 & 0.45 & 0.00 & 1.00 \\
LOSS & 1.16 & 0.00 & 1.89 & -2.54 & 9.85 \\
HIGH_TECH & 0.59 & 1.00 & 0.49 & 0.00 & 1.00 \\
DISACC & -0.25 & 0.01 & 4.14 & -44.09 & 29.43 \\
WOFFS & 0.01 & 0.00 & 0.08 & 0.00 & 1.00 \\
LNAUFEE & 0.35 & 0.21 & 1.45 & -2.90 & 4.22 \\
\hline
\end{tabular}

*Note:

The Table presents descriptive statistics for client firm variables used in the firm-year level empirical analyses. The sample includes all listed companies in Sweden during 1999-2007. Variables are defined as follows (firm and year subscripts omitted):

- CONV_AUD1 - An indicator variable that obtains a value of "1" if at least one audit partner who audit the firm has been convicted/suspected of a crime, and otherwise " 0 ";

- CONV_AUD2 - The number of convicted audit partners auditing a firm. The maximum number of convicted audit partners per firm-year is 3, so CONV_AUD2 $\in[0,3]$;

- $C O N V \_A U D 3$ - The number of convicted audit partners divided by the total number of audit partners auditing the firm;

- CURRENT - Current ratio = Current Assets / Current Liabilities;

- $\quad$ LEVERAGE - Financial leverage = Interest Bearing Debt / Total Assets;

- COVERAGE - Interest coverage ratio $=\mathrm{Ln}([\mathrm{EBIT}+\min (\mathrm{EBIT})] /$ Interest Expenses $)$, where EBIT is Earnings Before Interest Expenses and Taxes and min(EBIT) is the minimum value of EBIT in the sample;

- $\quad$ SIZE - The natural logarithm of total assets;

- $\quad P B-$ Price-to-book ratio = Market Value of Equity / Book Value of Equity; 
- $\quad C O N V \_D I R$ - The proportion of board members who have been convicted of a crime;

- CONV_OWNER - A indicator variable that obtains a value of " 1 " if the firm has at least one owner who owns $10 \%$ or more of the firm's equity and who has been convicted of a crime, and otherwise " 0 ";

- $O U T \_D I R$ - The proportion of directors with three or more board memberships in the listed Swedish firms (board professionals);

- BIG5 - An indicator variable that obtains a value of "1" if the firm is audited by a Big-5 audit firms (Ernst \& Young, KPMG, PWC, Deloitte, and Arthur Andersen) and otherwise " 0 ";

- $\quad R O A$ - Return-on-assets ratio, earnings before extraordinary and non-recurring items divided by total assets;

- FOREIGN - The proportion of sales generated by foreign operations;

- EXCEPTION - An indicator variable that obtains a value of "1", if the firm reports exceptional or extraordinary items, and otherwise " 0 ";

- LOSS - The logarithm of the absolute value of earnings if earnings are negative and otherwise "0";

- HIGH_TECH - An indicator variable that obtains a value of "1" if the firm belongs to a high-tech industry, and otherwise "0". Classification is based on OECD 2-digit SIC code classification (2-digit codes: 28, 35, 36, 37, 38, 48, 73 and 87, are classified as high-tech).

- DISACC - Discretionary accruals, measured as the Jones (1991) model residuals. Model parameters are first estimated for 2-digit industries; firm-specific residuals are then calculated using these parameters.

- WOFFS - The proportion of goodwill that is written off, measured as goodwill writeoffs divided by the amount of goodwill before the writeoff.

- $\quad$ LNAUFEE - The natural logarithm of the audit fee paid by the firm. 
Table 5

Selected Correlations*

\begin{tabular}{|c|c|c|c|c|c|c|c|c|c|c|c|c|c|}
\hline & & 1 & 2 & 3 & 4 & 5 & 6 & 7 & 8 & 9 & 10 & 11 & 12 \\
\hline 1 & CONV_AUD2 & & 0.08 & 0.10 & -0.04 & -0.03 & -0.09 & 0.12 & -0.11 & 0.03 & -0.05 & 0.05 & 0.08 \\
\hline 2 & CONV_DIR & 0.08 & & 0.27 & 0.04 & -0.06 & -0.10 & 0.03 & 0.04 & -0.05 & -0.02 & -0.11 & -0.07 \\
\hline 3 & CONV_OWNER & 0.09 & 0.26 & & 0.01 & -0.04 & -0.10 & 0.00 & 0.07 & 0.06 & -0.03 & -0.11 & -0.08 \\
\hline 4 & $O U T \_\overline{D I R}$ & -0.02 & 0.02 & -0.00 & & 0.13 & -0.12 & 0.05 & -0.34 & 0.11 & -0.08 & 0.37 & 0.37 \\
\hline 5 & $B I G 5$ & -0.03 & -0.07 & -0.04 & 0.14 & & -0.09 & 0.11 & -0.23 & 0.10 & -0.01 & 0.27 & 0.26 \\
\hline 6 & CURRENT & -0.04 & -0.09 & -0.04 & -0.11 & -0.08 & & -0.29 & 0.37 & -0.16 & 0.07 & -0.26 & -0.34 \\
\hline 7 & LEVERAGE & 0.10 & 0.04 & -0.00 & 0.08 & 0.10 & -0.35 & & -0.61 & 0.12 & -0.15 & 0.39 & 0.36 \\
\hline 8 & COVERAGE & -0.11 & 0.03 & 0.08 & -0.28 & -0.23 & 0.39 & -0.51 & & -0.26 & 0.15 & -0.83 & -0.79 \\
\hline 9 & $R O A$ & -0.03 & -0.09 & 0.04 & 0.11 & 0.10 & 0.03 & 0.06 & -0.28 & & 0.06 & 0.43 & 0.36 \\
\hline 10 & $P B$ & -0.07 & -0.04 & -0.05 & -0.04 & 0.05 & 0.08 & -0.19 & 0.14 & 0.25 & & -0.11 & -0.10 \\
\hline 11 & SIZE & 0.04 & -0.09 & -0.10 & 0.41 & 0.28 & -0.28 & 0.44 & -0.76 & 0.40 & -0.08 & & 0.92 \\
\hline 12 & LNAUFEE & 0.08 & -0.05 & -0.07 & 0.40 & 0.28 & -0.35 & 0.43 & -0.73 & 0.33 & -0.07 & 0.91 & \\
\hline
\end{tabular}

*Note: The table presents pair-wise Pearson's (upper diagonal) and Spearman's (lower diagonal) correlations for selected client firm variables. Correlations above 0.05 and below -0.05 are significant at the 0.05 level. The sample includes 1,588 firm-year observations for Swedish listed companies during 1999-2007. See Table 4 for variable definitions. 


\section{Table 6}

Financial and Governance Risk of Client Firms*

\begin{tabular}{|c|c|c|c|c|c|}
\hline & \multicolumn{4}{|c|}{$\begin{array}{c}\text { Number of Convicted/Suspected Audit Partners } \\
\text { Appointed by a Firm }\end{array}$} & \multirow[b]{2}{*}{$\begin{array}{c}\text { Difference } \\
\text { between 'Zero' } \\
\text { and 'At least } \\
\text { one' }\end{array}$} \\
\hline & $\begin{array}{c}\text { Zero } \\
(\mathrm{N}=\mathbf{1 , 0 4 8})\end{array}$ & $\begin{array}{c}\text { One } \\
(\mathrm{N}=\mathbf{4 8 2})\end{array}$ & $\begin{array}{c}\text { Two or } \\
\text { more } \\
(\mathrm{N}=58)\end{array}$ & $\begin{array}{c}\text { At least } \\
\text { one } \\
(\mathrm{N}=\mathbf{5 4 0})\end{array}$ & \\
\hline & $\begin{array}{c}\text { Mean } \\
\text { Median }\end{array}$ & $\begin{array}{c}\text { Mean } \\
\text { Median }\end{array}$ & $\begin{array}{c}\text { Mean } \\
\text { Median }\end{array}$ & $\begin{array}{c}\text { Mean } \\
\text { Median }\end{array}$ & $\begin{array}{c}\text { t-test } \\
\text { Wilcoxon test }\end{array}$ \\
\hline \multirow[t]{2}{*}{ CURRENT } & 2.27 & 1.98 & 1.83 & 1.96 & $3.60++$ \\
\hline & 1.77 & 1.73 & 1.63 & 1.72 & $1.67 *$ \\
\hline \multirow[t]{2}{*}{ LEVERAGE } & 0.16 & 0.19 & 0.25 & 0.19 & $-4.10++$ \\
\hline & 0.13 & 0.17 & 0.25 & 0.18 & $-4.05++$ \\
\hline \multirow[t]{2}{*}{ COVERAGE } & 7.90 & 7.44 & 6.03 & 7.29 & $3.16++$ \\
\hline & 7.89 & 7.47 & 5.95 & 7.21 & 3.78++ \\
\hline \multirow[t]{2}{*}{ SIZE } & 6.75 & 6.87 & 7.30 & 6.91 & -1.57 \\
\hline & 6.56 & 6.46 & 7.43 & 6.69 & -1.30 \\
\hline \multirow[t]{2}{*}{$P B$} & 2.95 & 2.69 & 2.79 & 2.70 & 1.99+ \\
\hline & 2.21 & 2.01 & 1.65 & 2.00 & $2.69++$ \\
\hline \multirow[t]{2}{*}{ ROA } & 0.00 & 0.01 & 0.05 & 0.01 & -0.79 \\
\hline & 0.07 & 0.06 & 0.06 & 0.06 & -1.29 \\
\hline \multirow[t]{2}{*}{ DISACC } & -0.43 & -0.02 & 1.01 & 0.09 & $-2.38+$ \\
\hline & 0.01 & 0.01 & 0.01 & 0.01 & -0.48 \\
\hline \multirow[t]{2}{*}{ WOFFS } & 0.02 & 0.01 & 0.01 & 0.01 & $-1.81+$ \\
\hline & 0.00 & 0.00 & 0.00 & 0.00 & -0.29 \\
\hline \multirow[t]{2}{*}{ CONV_DIR } & 0.28 & 0.30 & 0.35 & 0.31 & $-2.83++$ \\
\hline & 0.25 & 0.29 & 0.32 & 0.23 & $-2.88++$ \\
\hline \multirow[t]{2}{*}{ CONV_OWNER } & 0.26 & 0.34 & 0.40 & 0.35 & $3.62++$ \\
\hline & 0.00 & 0.00 & 0.00 & 0.00 & $3.60++$ \\
\hline \multirow[t]{2}{*}{ OUT_DIR } & 0.17 & 0.15 & 0.15 & 0.15 & 1.51 \\
\hline & 0.14 & 0.14 & 0.17 & 0.14 & -0.94 \\
\hline \multirow[t]{2}{*}{ LNAUFEE } & 0.27 & 0.44 & 0.88 & 0.49 & $-2.78++$ \\
\hline & 0.14 & 0.26 & 0.90 & 0.34 & $-2.74++$ \\
\hline
\end{tabular}


*Notes:

1. The table presents mean and median variables for sub-samples of Swedish listed firms that are not audited by convicted/suspected audit partners (1,048 observations), that are audited by one convicted/suspected audit partner (482 observations), that are audited by two or more convicted/suspected audit partners (58 observations), and that are audited by at least one convicted/suspected audit partner (540 observations). Data are from the period 1999-2007.

2. The table also presents results for the difference in means (t-test) and medians (Wilcoxon test) between firms without convicted/suspected auditors and firms with at least one convicted/suspected auditor.

3. See Table 4 for variable definitions.

4.,,$+++ *$ denote significance levels at the $0.01,0.05$ and 0.10 levels respectively. 
Table 7

Multivariate Logistic Regressions of Pooled Firm-Year Data*

\begin{tabular}{|c|c|c|c|}
\hline Variable & $\begin{array}{l}\text { Exp. } \\
\text { Sign }\end{array}$ & $\begin{array}{c}\text { All } \\
\text { Coefficient } \\
\text { (chi-sqr) }\end{array}$ & $\begin{array}{c}\text { Big-5 } \\
\text { Coefficient } \\
\text { (chi-sqr) }\end{array}$ \\
\hline Intercept & $?$ & $\begin{array}{c}2.04 \\
(4.25)+\end{array}$ & $\begin{array}{l}-3.39 \\
(9.36)++\end{array}$ \\
\hline CURRENT & - & $\begin{array}{l}-0.07 \\
(2.23)\end{array}$ & $\begin{array}{l}-0.05 \\
(0.94)\end{array}$ \\
\hline LEVERAGE & + & $\begin{array}{c}0.56 \\
(1.62)\end{array}$ & $\begin{array}{c}0.54 \\
(1.34)\end{array}$ \\
\hline COVERAGE & - & $\begin{array}{l}-0.07 \\
(3.97)+\end{array}$ & $\begin{array}{l}-0.05 \\
(2.08)\end{array}$ \\
\hline$S I Z E$ & - & $\begin{array}{l}-0.30 \\
(11.56)++\end{array}$ & $\begin{array}{l}-0.25 \\
(6.78)++\end{array}$ \\
\hline$P B$ & + & $\begin{array}{l}-0.01 \\
(0.17)\end{array}$ & $\begin{array}{c}0.02 \\
(0.36)\end{array}$ \\
\hline $\boldsymbol{R O A}$ & - & $\begin{array}{l}-0.07 \\
(0.02)\end{array}$ & $\begin{array}{l}-0.11 \\
(0.05)\end{array}$ \\
\hline DISACC & + & $\begin{array}{c}0.04 \\
(5.64)+\end{array}$ & $\begin{array}{c}0.06 \\
(7.83)++\end{array}$ \\
\hline WOFFS & - & $\begin{array}{l}-1.57 \\
(2.83)^{*}\end{array}$ & $\begin{array}{l}-1.85 \\
(3.12) *\end{array}$ \\
\hline CONV_DIR & + & $\begin{array}{c}0.60 \\
(3.55) *\end{array}$ & $\begin{array}{c}0.92 \\
(7.39)++\end{array}$ \\
\hline CONV_OWNER & + & $\begin{array}{c}0.30 \\
(5.45)+\end{array}$ & $\begin{array}{l}0.23 \\
(2.75) *\end{array}$ \\
\hline OUT_DIR & - & $\begin{array}{l}-0.68 \\
(2.91)^{*}\end{array}$ & $\begin{array}{l}-1.00 \\
(5.47)+\end{array}$ \\
\hline LNAUFEE & + & $\begin{array}{c}0.41 \\
(13.26)++\end{array}$ & $\begin{array}{c}0.39 \\
(10.54)++\end{array}$ \\
\hline FOREIGN & $?$ & $\begin{array}{l}-0.29 \\
(1.88)\end{array}$ & $\begin{array}{l}-0.33 \\
(2.20)\end{array}$ \\
\hline EXCEPTION & $?$ & $\begin{array}{l}-0.13 \\
(0.83)\end{array}$ & $\begin{array}{l}-0.16 \\
(1.10)\end{array}$ \\
\hline LOSS & $?$ & $\begin{array}{c}0.01 \\
(0.02)\end{array}$ & $\begin{array}{c}0.01 \\
(0.03)\end{array}$ \\
\hline HIGH_TECH & $?$ & $\begin{array}{l}-0.12 \\
(0.64)\end{array}$ & $\begin{array}{l}-0.11 \\
(0.42)\end{array}$ \\
\hline$A G E$ & + & $\begin{array}{c}0.05 \\
(25.67)++\end{array}$ & $\begin{array}{c}\mathbf{0 . 0 6} \\
(27.64)++\end{array}$ \\
\hline GENDER & + & $\begin{array}{c}0.91 \\
(4.91)+\end{array}$ & $\begin{array}{l}1.22 \\
(6.00)+\end{array}$ \\
\hline
\end{tabular}




\begin{tabular}{lccc}
\hline CLIENTS & + & -0.00 & -0.00 \\
& & $(0.62)$ & $(0.56)$ \\
BIG5 & - & -0.27 & -- \\
& & $(2.03)$ & \\
\hline Industry fixed-effects & Yes & Yes \\
Year fixed-effects & Yes & Yes \\
Vuong test: Financial risk & & $\mathbf{2 1 . 8 6 + +}$ & $\mathbf{2 1 . 6 5 + +}$ \\
Vuong test: Governance risk & & $\mathbf{1 3 . 8 3 + +}$ & $\mathbf{1 7 . 0 0 + +}$ \\
Observations & 1,588 & 1,425 \\
\hline
\end{tabular}

*Notes:

1. The table presents results of estimating Equation (2):

$$
\begin{aligned}
& \text { CONV_AUD } 1_{j t}=\beta_{0}+\beta_{1} \text { CURRENT }_{j t}+\beta_{2} \text { LEVERAGE }_{j t}+\beta_{3} \text { COVERAGE }_{j t}+\beta_{4} \text { SIZE }_{j t} \\
& +\beta_{5} \text { PB }_{j t}+\beta_{6} \text { ROA }_{j t}+\beta_{7} \text { DISACC }_{j t}+\beta_{8} \text { WOFFS }_{j t}+\beta_{9} \text { CONV_DIR }_{j t}+\beta_{10} \text { CONV_OWNER }_{j t} \\
& +\beta_{11} O U T_{-} \text {DIR }_{j t}+\beta_{12} \text { LNAUFEE }_{j t}+\beta_{13} \text { FOREIGN }_{j t}+\beta_{14} \text { EXCEPTION }_{j t}+\beta_{15} \text { LOSS }_{j t} \\
& +\beta_{16} \text { HIGH_TECH }_{j t}+\beta_{17} \text { AGE } \\
& j t
\end{aligned}
$$

2. The dependent variable is $C O N V \_A U D 1$ (an indicator variable that obtains a value "1" if the firm has at least one convicted/suspected audit partner, and otherwise " $0 ") . A G E$ is the average age of audit partners auditing the firm, GENDER is the average over the audit partners auditing the firm of an indicator variable that is equal to " 1 " if the audit partner is a male and " 0 " if a female, and CLIENTS is the average over audit partners of the number of client-firms audited by each audit partner. All other independent variables are defined in Table 4.

3. The sample includes 1,588 firm-year observations for Swedish listed firms during 19992007. 558 firm-year observations have at least one convicted/suspected audit partner, whereas 1,101 firm-year observations have zero convicted/suspected audit partners.

4.,,$+++ *$ denote significance levels at the $0.01,0.05$ and 0.10 levels respectively. 
Table 8

Conditional Conservatism of Client Firms*

\begin{tabular}{|c|c|c|c|}
\hline & & $\mathbf{A L L}$ & Big-5 \\
\hline Variable & $\begin{array}{l}\text { Exp. } \\
\text { Sign }\end{array}$ & $\begin{array}{c}\text { Coefficient } \\
\text { (t-value) }\end{array}$ & $\begin{array}{c}\text { Coefficient } \\
\text { (t-value) }\end{array}$ \\
\hline$R E T$ & + & $\begin{array}{c}0.00 \\
(0.11)\end{array}$ & $\begin{array}{c}0.01 \\
(0.54)\end{array}$ \\
\hline DRET & $?$ & $\begin{array}{c}-0.03 \\
(-0.75)\end{array}$ & $\begin{array}{c}-0.03 \\
(-0.68)\end{array}$ \\
\hline$R E T \times D R E T$ & + & $\begin{array}{l}0.63 \\
(4.50)++\end{array}$ & $\begin{array}{l}0.59 \\
(3.72)++\end{array}$ \\
\hline CONV_AUD2 & $?$ & $\begin{array}{l}-0.02 \\
(-1.27)\end{array}$ & $\begin{array}{l}-0.01 \\
(-0.91)\end{array}$ \\
\hline $\mathrm{RET} \times \mathrm{CONV}_{-} \mathrm{AUD} 2$ & + & $\begin{array}{c}\mathbf{0 . 0 3} \\
(1.73)^{*}\end{array}$ & $\begin{array}{l}\mathbf{0 . 0 3} \\
(\mathbf{2 . 0 4})+\end{array}$ \\
\hline$D R E T \times C O N V_{-} A U D 2$ & $?$ & $\begin{array}{c}0.01 \\
(0.44)\end{array}$ & $\begin{array}{c}-0.01 \\
(-0.36)\end{array}$ \\
\hline$R E T \times D R E T \times C O N V_{-} A U D 2$ & - & $\begin{array}{l}-0.10 \\
(-2.09)+\end{array}$ & $\begin{array}{l}-0.11 \\
(-2.28)+\end{array}$ \\
\hline$S I Z E$ & $?$ & $\begin{array}{l}0.02 \\
(6.06)++\end{array}$ & $\begin{array}{l}0.02 \\
(5.75)++\end{array}$ \\
\hline LEVERAGE & $?$ & $\begin{array}{l}-0.23 \\
(-4.39)++\end{array}$ & $\begin{array}{l}-0.21 \\
(-4.14)++\end{array}$ \\
\hline$P B$ & $?$ & $\begin{array}{l}-0.01 \\
(-3.77)++\end{array}$ & $\begin{array}{l}-0.01 \\
(-3.45)++\end{array}$ \\
\hline$R E T \times S I Z E$ & $?$ & $\begin{array}{l}-0.00 \\
(0.09)\end{array}$ & $\begin{array}{l}-0.00 \\
(-0.66)\end{array}$ \\
\hline$R E T \times L E V E R A G E$ & $?$ & $\begin{array}{l}0.25 \\
(2.80)++\end{array}$ & $\begin{array}{l}0.26 \\
(3.00)++\end{array}$ \\
\hline$R E T \times P B$ & $?$ & $\begin{array}{l}-0.00 \\
(-0.51)\end{array}$ & $\begin{array}{c}0.00 \\
(0.27)\end{array}$ \\
\hline$D R E T \times S I Z E$ & $?$ & $\begin{array}{c}-0.00 \\
(-0.51)\end{array}$ & $\begin{array}{l}-0.00 \\
(-0.45)\end{array}$ \\
\hline$D R E T \times L E V E R A G E$ & $?$ & $\begin{array}{c}0.08 \\
(0.96)\end{array}$ & $\begin{array}{c}0.08 \\
(0.81)\end{array}$ \\
\hline$D R E T \times P B$ & $?$ & $\begin{array}{c}0.01 \\
(1.63)\end{array}$ & $\begin{array}{c}0.01 \\
(1.47)\end{array}$ \\
\hline$R E T \times D R E T \times S I Z E$ & $?$ & $\begin{array}{c}-0.05 \\
(-2.44)+\end{array}$ & $\begin{array}{l}-0.04 \\
(-1.92) *\end{array}$ \\
\hline$R E T \times D R E T \times L E V E R A G E$ & $?$ & $\begin{array}{c}0.02 \\
(0.08)\end{array}$ & $\begin{array}{c}0.02 \\
(0.07)\end{array}$ \\
\hline$R E T \times D R E T \times P B$ & $?$ & $\begin{array}{l}-0.04 \\
(-2.07)+\end{array}$ & $\begin{array}{c}-0.03 \\
(-1.60)\end{array}$ \\
\hline
\end{tabular}




\begin{tabular}{lcc}
\hline Yearly fixed effects & Yes & Yes \\
Firm fixed effects & Yes & Yes \\
Observations & 1,588 & 1,425 \\
Adj- $^{2}$ & 0.30 & 0.29 \\
\hline
\end{tabular}

Notes:

1. The table presents results of estimating Equation (3):

$$
\begin{aligned}
& E P_{j t}=\delta_{0}+\delta_{1} R E T_{j t}+\delta_{2} D R E T_{j t}+\delta_{3} R E T_{j t} \times D R E T_{j t}+\delta_{4} C O N V_{-} A U D 2_{j t} \\
& +\delta_{5} R E T_{j t} \times C O N C_{-} A U D 2_{j t}+\delta_{6} D R E T_{j t} \times C O N V_{-} A U D 2_{j t} \\
& +\delta_{7} R E T_{j t} \times D R E T_{j t} \times C O N V_{-} A U D 2_{j t}+\delta_{8} S I Z E_{j t}+\delta_{9} L E V E R A G E_{j t}+\delta_{10} P B_{j t} \\
& +\delta_{11} R E T_{j t} \times S I Z E_{j t}+\delta_{12} R E T_{j t} \times L E V E R A G E_{j t}+\delta_{13} R E T_{j t} \times P B_{j t}+\delta_{14} D R E T_{j t} \times S I Z E_{j t} \\
& +\delta_{15} D R E T_{j t} \times L E V E R A G E_{j t}+\delta_{16} D R E T_{j t} \times P B_{j t}+\delta_{17} R E T_{j t} \times D R E T_{j t} \times S I Z E_{j t} \\
& +\delta_{18} R E T_{j t} \times D R E T_{j t} \times L E V E R A G E_{j t}+\delta_{19} R E T_{j t} \times D R E T_{j t} \times P B_{j t}+v_{j t} .
\end{aligned}
$$

The dependent variable $(E P)$ is annual earnings per share divided by the beginning-of-year share price. Independent variables include RET (annual stock return); DRET (an indicator variable that obtains a value "1" if $R E T$ is negative, and otherwise "0"); CONV_AUD2 (The number of convicted auditors auditing a firm); SIZE (the natural logarithm of total assets), LEVERAGE (interest bearing debt divided by total assets, and $P B$ (market value of equity divided by book value of equity).

2. The sample includes 1,588 firm-year observations for Swedish listed firms during 19992007.

3. All $t$-values are based on heteroskedasticity-adjusted standard errors. The firm-level clustering in standard errors is taken into account as in Petersen (2009).

4.,,$+++ *$ denote significance levels at the $0.01,0.05$ and 0.10 levels respectively. 
Table 9

Audit Fees and Convicted/Suspected Auditors*

\begin{tabular}{|c|c|c|c|}
\hline Variable & Sign & $\mathbf{A L L}$ & Big-5 \\
\hline CONV_AUD2 & + & $\begin{array}{c}\text { 0.08 } \\
(2.42)+\end{array}$ & $\begin{array}{c}\text { 0.06 } \\
(1.73)^{*}\end{array}$ \\
\hline CURRENT & - & $\begin{array}{c}-0.05 \\
(-4.13)++\end{array}$ & $\begin{array}{l}-0.06 \\
(-4.70)++\end{array}$ \\
\hline LEVERAGE & + & $\begin{array}{c}0.13 \\
(0.94)\end{array}$ & $\begin{array}{c}0.05 \\
(0.35)\end{array}$ \\
\hline COVERAGE & - & $\begin{array}{c}-0.02 \\
(-1.94) *\end{array}$ & $\begin{array}{c}-0.02 \\
(-1.88) *\end{array}$ \\
\hline$P B$ & + & $\begin{array}{c}0.00 \\
(0.18)\end{array}$ & $\begin{array}{c}0.00 \\
(0.99)\end{array}$ \\
\hline$S I Z E$ & + & $\begin{array}{c}0.58 \\
(29.78)++\end{array}$ & $\begin{array}{c}0.57 \\
(27.56)++\end{array}$ \\
\hline$R O A$ & - & $\begin{array}{l}-0.23 \\
(-2.13)+\end{array}$ & $\begin{array}{c}-0.31 \\
(-2.63)++\end{array}$ \\
\hline FOREIGN & + & $\begin{array}{c}0.10 \\
(1.64)\end{array}$ & $\begin{array}{c}0.13 \\
(2.20)+\end{array}$ \\
\hline EXCEPTION & + & $\begin{array}{c}0.10 \\
(4.11)++\end{array}$ & $\begin{array}{c}0.11 \\
(4.47)++\end{array}$ \\
\hline LOSS & + & $\begin{array}{c}0.01 \\
(1.45)\end{array}$ & $\begin{array}{c}0.01 \\
(0.83)\end{array}$ \\
\hline HIGH_TECH & + & $\begin{array}{c}0.15 \\
(2.53)++\end{array}$ & $\begin{array}{c}0.17 \\
(2.68)++\end{array}$ \\
\hline BIG5 & + & $\begin{array}{c}0.11 \\
(1.60)\end{array}$ & -- \\
\hline CURRENT $\times C O N V \_A U D 2$ & + & $\begin{array}{c}0.02 \\
(0.76)\end{array}$ & $\begin{array}{c}0.02 \\
(0.91)\end{array}$ \\
\hline LEVERAGE $\times$ CONV_AUD2 & - & $\begin{array}{l}-0.27 \\
(-1.75) *\end{array}$ & $\begin{array}{l}-0.28 \\
(-1.68) *\end{array}$ \\
\hline COVERAGE $\times$ CONV_AUD2 & + & $\begin{array}{c}0.02 \\
(2.47)+\end{array}$ & $\begin{array}{l}0.02 \\
(2.64)++\end{array}$ \\
\hline$S I Z E \times C O N V \_A U D 2$ & - & $\begin{array}{c}-0.02 \\
(-1.12)\end{array}$ & $\begin{array}{c}-0.01 \\
(-0.76)\end{array}$ \\
\hline$P B \times C O N V \_A U D 2$ & - & $\begin{array}{c}-0.01 \\
(-1.29)\end{array}$ & $\begin{array}{c}-0.01 \\
(-0.92)\end{array}$ \\
\hline Yearly fixed effects & & Yes & Yes \\
\hline Firm fixed effects & & Yes & Yes \\
\hline Observations & & 1,588 & 1,425 \\
\hline Adj-R $\mathbf{R}^{2}$ & & 0.89 & 0.89 \\
\hline
\end{tabular}


*Notes:

1. The table presents results of estimating Equation (4):

$$
\begin{aligned}
& \text { LNAUFEE }_{j t}=\gamma_{0}+\gamma_{1} \text { CONV_AUD2 }_{j t}+\gamma_{2} \text { CURRENT }_{j t}+\gamma_{3} \text { LEVERAGE }_{j t}+\gamma_{4} \text { COVERAGE }_{j t} \\
& +\gamma_{5} P_{j t}+\gamma_{6} \text { SIZE }_{j t}+\gamma_{7} \text { ROA }_{j t}+\gamma_{8} \text { FOREIGN }_{j t}+\gamma_{9} \text { EXCEPTION }_{j t}+\gamma_{10} \text { LOSS }_{j t}+ \\
& \gamma_{11} \mathrm{HIGH}_{-} \mathrm{TECH}_{j t}+\gamma_{12} \text { BIG5 }_{j t}+\gamma_{13} \mathrm{CURRENT}_{j t} x \mathrm{CONV} \mathrm{AUD}_{j t}+
\end{aligned}
$$

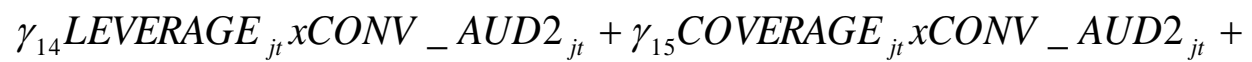

$$
\begin{aligned}
& \gamma_{16} P B_{j t} x C O N V_{-} A U D 2_{j t}+\gamma_{17} S I Z E_{j t} x C O N V_{-} A U D 2_{j t}+\vartheta_{j t} \text {. }
\end{aligned}
$$

The dependent variable is the log of total audit fees (LNAUFEE). All independent variables are defined in Table 4.

2. The sample includes 1,588 firm-year observations for Swedish listed firms during 19992007.

3. All $t$-values are based on heteroskedasticity-adjusted standard errors. The firm-level clustering in standard errors is taken into account as in Petersen (2009).

4.,,$+++ *$ denote significance levels at the $0.01,0.05$ and 0.10 levels respectively. 